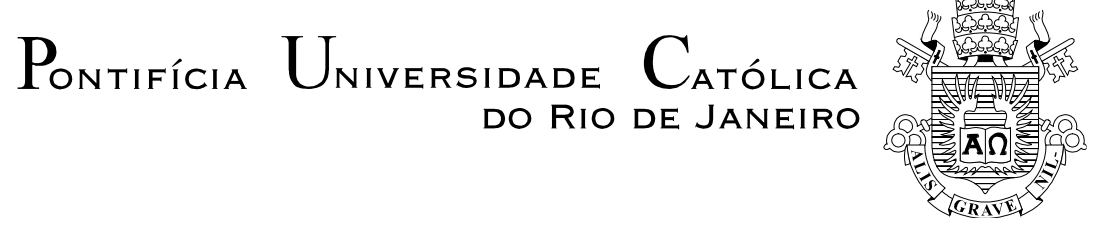

Vanessa Rodrigues Tinoco

Educação Financeira: uma abordagem no Ensino Fundamental - anos finais

Dissertação de Mestrado

Dissertação apresentada como requisito parcial para obtenção do grau de Mestre pelo Programa de PósGraduação em Matemática do Departamento de Matemática da PUC-Rio.

Orientador: Prof. Marcos Craizer

Rio de Janeiro

Setembro de 2020 


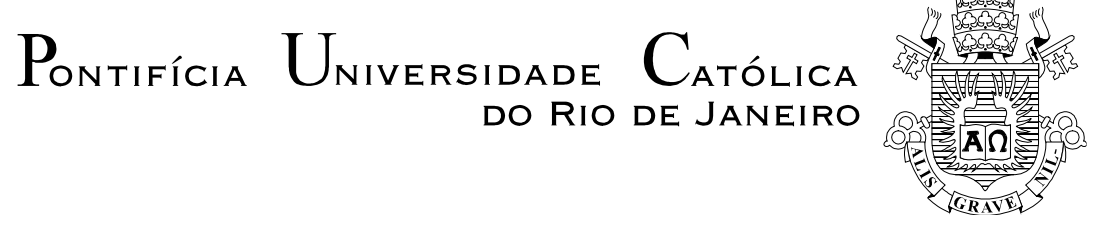

Vanessa Rodrigues Tinoco

Educação Financeira: uma abordagem no Ensino Fundamental - anos finais.

Dissertação de Mestrado

Dissertação apresentada como requisito parcial para obtenção do grau de Mestre pelo Programa de PósGraduação em Matemática da PUC-Rio. Aprovada pela Comissão Examinadora abaixo:

Prof. Marcos Craizer

Orientador

Departamento de Matemática - PUC-Rio

Profa. Dirce Uesu Pesco

Instituto de Matemática e Estatística - UFF

Profa. Renata Martins Rosa

Departamento de Matemática - PUC-Rio

Rio de Janeiro, 24 de Setembro de 2020 
Todos os direitos reservados. É proibida a reprodução total ou parcial do trabalho sem autorização da universidade, do autor e do orientador.

\section{Vanessa Rodrigues Tinoco}

Graduou-se em Licenciatura Plena em Matemática pela Universidade do Estado do Rio de Janeiro na Faculdade de Formação de Professores, campus São Gonçalo. Atualmente exerce o cargo de Docente de Matemática da Secretaria Estatual de Educação do Estado do Rio de Janeiro (SEEDUC-RJ) e da Secretaria Municipal de Educação de São Gonçalo (SEMED-SG), ministrando aulas para o ensino fundamental e médio.

Ficha Catalográfica

Tinoco, Vanessa Rodrigues

Educação Financeira : uma abordagem no Ensino Fundamental anos finais / Vanessa Rodrigues Tinoco ; orientador: Marcos Craizer. 2020.

59 f. : il. color. ; $30 \mathrm{~cm}$

Dissertação (mestrado)-Pontifícia Universidade Católica do Rio de Janeiro, Departamento de Matemática, 2020.

Inclui bibliografia

1. Matemática - Teses. 2. Educação financeira. 3. Matemática financeira. 4. Ensino fundamental. 5. Atividades. I. Craizer, Marcos. II. Pontifícia Universidade Católica do Rio de Janeiro. Departamento de Matemática. III. Título. 
Para meus pais, Vania e Nelson, por todo amor, apoio e confiança. E para meu marido, Bruno e meu filho, Júlio César, por serem minha fonte de inspiração. 


\section{Agradecimentos}

Ao meu orientador, professor Marcos Craizer, que me deu todo apoio necessário durante o processo de produção deste trabalho e não me deixou desistir quando pensei que não conseguiria prosseguir.

A todos os professores da PUC-Rio pelos ensinamentos em cada disciplina cursada no PROFMAT.

A todos os meus colegas de turma pela parceria em todos os sábados e troca de experiências.

À PUC-Rio e à CAPES pela oportunidade e apoio institucional.

À direção do Colégio Estadual Monsenhor Barenco Coelho, da Escola Municipal Luiz Gonzaga e Escola Municipal Professora Aurelina Cavalcanti Dias, pela confiança e oportunidade de permitir aplicação das atividades propostas da minha pesquisa.

Ao meu marido, Bruno, que participou ativamente deste trabalho me auxiliando na formatação e correção do texto. Além de me apoiar e incentivar sempre para que eu alce voos mais altos.

Aos membros que participaram da banca avaliadora dessa dissertação.

Aos meus pais, Vania e Nelson, que me incentivaram desde o início deste projeto, e que cuidaram do meu bebê, transbordando todo o seu amor, para que eu pudesse assistir as aulas.

Ao meu filho, Júlio César, que durante toda a construção deste trabalho foi a minha maior motivação e inspiração.

O presente trabalho foi realizado com apoio da Coordenação de Aperfeiçoamento de Pessoal de Nível Superior - Brasil (CAPES) - Código de Financiamento 001. 


\section{Resumo}

Tinoco, Vanessa Rodrigues; Craizer, Marcos; Educação Financeira: uma abordagem no Ensino Fundamental - anos finais. Rio de Janeiro, 2020. 59p. Dissertação de Mestrado - Departamento de Matemática, Pontifícia Universidade Católica do Rio de Janeiro.

Esta dissertação traz como eixo central propostas de atividades que contextualizam a teoria da matemática financeira com sua prática através da educação financeira com o objetivo despertar nos alunos o interesse pelo tema para que eles construam os conhecimentos necessários para a tomada consciente de decisões financeira e seu planejamento financeiro individual. As atividades foram aplicadas em turmas de $8^{\circ}$ ano e $9^{\circ}$ ano do segundo segmento do Ensino Fundamental de duas escolas da rede pública municipal e uma escola da rede pública estadual, todas localizadas no município de São Gonçalo. Apresentamos os conceitos e fundamentos da matemática financeira e da educação financeira necessários para discussão das atividades. Os resultados das aplicações das atividades foram discutidos no capítulo 4 e finalizamos com considerações finais acerca do tema. Espera-se que este trabalho possa colaborar com as práticas de outros docentes engajados na educação básica, comprometidos com a promoção de um ensino significativo e de qualidade para seu discente.

Palavras-chave: Educação Financeira; Matemática Financeira; Ensino Fundamental; Atividades; 


\section{Abstract}

Tinoco, Vanessa Rodrigues; Craizer, Marcos (Advisor); Financial Education: an approach in Middle School - final years. Rio de Janeiro, 2020. 59 p. Dissertação de Mestrado - Departamento de Matemática, Pontifícia Universidade Católica do Rio de Janeiro.

This dissertation brings as its central axis proposals for activities that contextualize the theory of financial mathematics with its practice through financial education with the aim of arousing student's interest in the topic so that they build the necessary knowledge for conscious financial decision-making and planning individual financial. The activities were applied in classes of 8th grade and 9th grade of Middle School in three public schools, all located in the county of São Gonçalo. We present the concepts and foundations of financial mathematics and financial education that are essential to discuss activities. The results of the applications of the activities were discussed in chapter 4 and we finish with final considerations on the theme. It is expected that this work collaborates with the practices of other teachers engaged in basic education, committed to the promotion of meaningful and quality teaching for their students.

Keywords: Financial education; Financial math; Middle School; Activities; 


\section{Sumário}

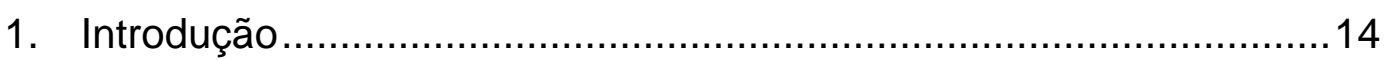

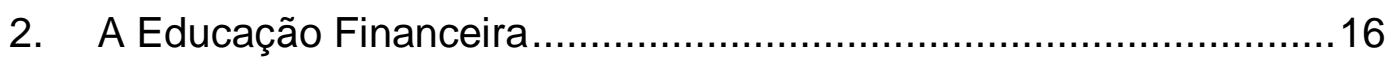

2.1. O que é Educação Financeira? ..............................................16

2.2. Estratégia Nacional de Educação Financeira - ENEF ................17

2.3. Educação Financeira e a Base Nacional Comum Curricular -

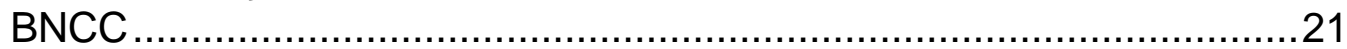

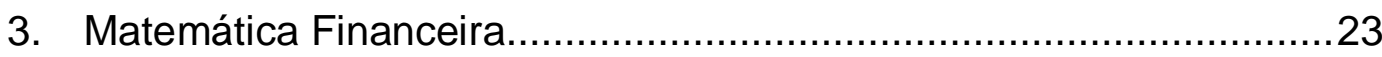

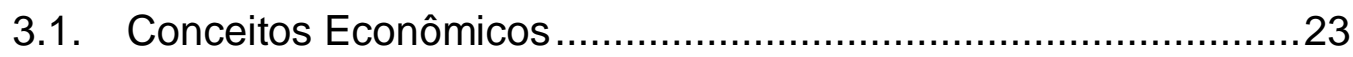

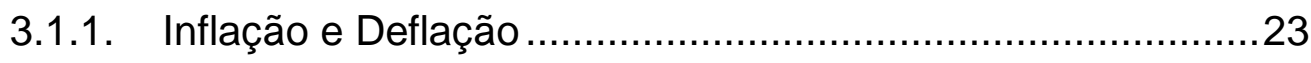

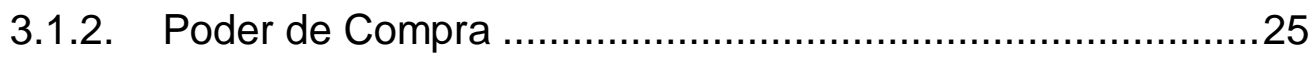

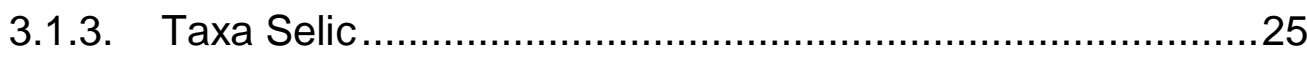

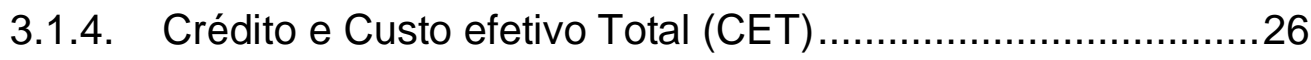

3.2. Conceitos Matemáticos ..........................................................27

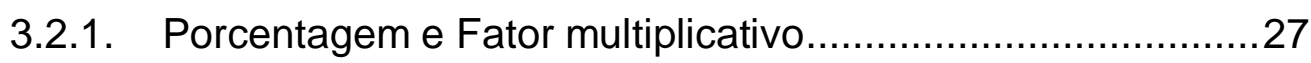

3.2.2. Juros Simples e Compostos ...............................................30

4. Análise das Atividades Aplicadas em Sala ......................................34

4.1. Atividade 1 - Questionário diagnóstico. .....................................34

4.2. Atividade 2 - Planejamento e Orçamento Doméstico. ...................41

4.3. Atividade 3 - Porcentagem e Juros........................................... 45

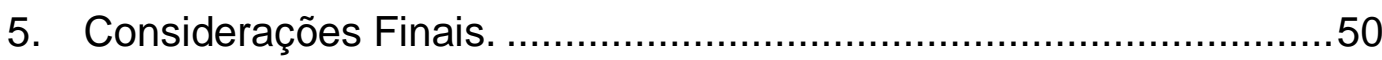

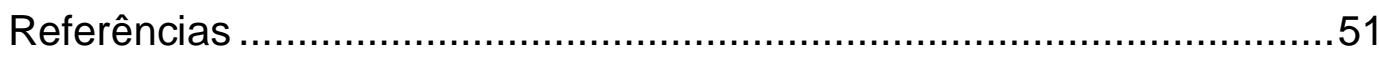

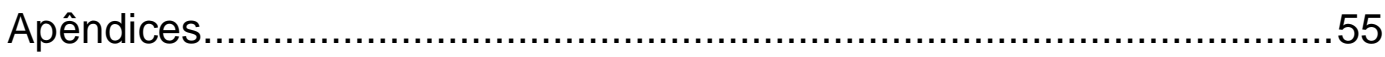

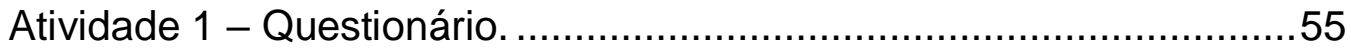

Atividade 2 - Planejamento e Orçamento Doméstico. …………….......56

Atividade 3 - Porcentagem e Juros. ……...........................................58 


\section{Lista de Figuras}

Figura 1: Finalidade da ENEF segundo decreto no 7397 de 2010. Fonte: BRASIL, Infográfico ENEF.

Figura 2: Dimensão temporal e espacial da Educação Financeira. Fonte: BRASIL. Programa de Educação Financeira nas Escolas: Modelo Conceitual e Objetivos. 2016

Figura 3: Programa Educação Financeira na Escolas - Livros para Ensino Médio. Fonte: disponíveis em $<$ https://www.vidaedinheiro.gov.br/livros-ensino-medio/>

Figura 4: Conjunto de livros para o Ensino Fundamenta criados com o apoio da B3 (Brasil, Bolsa e Balcão). Fonte: < https://www.vidaedinheiro.gov.br/livros-ensino-fundamental/>

Figura 5: Comparativo entre os rendimentos da poupança, antes e depois da mudança de 2012. Fonte: Site G1 < http://g1.globo.com/economia/seudinheiro/noticia/2012/05/veja-perguntas-e-respostas-sobre-mudancas-napoupanca.html>

Figura 6: Gráfico demonstrando a evolução dos juros ao longo do tempo. Fonte: A autora.

Figura 7: Gráfico comparativo entre um capital aplicado com juros simples e juros compostos. Fonte: ARAÚJO, Milton. Pílulas de Matemática Financeira (2). 2013. Disponível em: http://profmilton.blogspot.com.br/2013/12/pilulas-de-matematicafinanceira-2.html.

Figura 8: Gráfico de barras dos alunos que conhecem sobre inflação nas 3 escolas. Fonte: a autora.

Figura 9: Gráfico de barras dos alunos que conhecem pouco sobre inflação nas 3 escolas. Fonte: a autora.

Figura 10: Gráfico de barras dos alunos que desconhecem sobre inflação nas 3 escolas. Fonte: a autora.

Figura 11: Gráfico de barras dos alunos que conhecem sobre deflação nas 3 escolas. Fonte: a autora.

Figura 12: Gráfico de barras dos alunos que conhecem pouco sobre deflação nas 3 escolas.. Fonte: a autora. 
Figura 13: Gráfico de barras dos alunos que desconhecem sobre deflação nas 3 escolas. Fonte: a autora.

Figura 14: Gráfico de barras dos alunos que possuem bom entendimento sobre poder de compra nas 3 escolas. Fonte: a autora.

Figura 15: Gráfico de barras dos alunos que possuem pouco

entendimento sobre poder de compra nas 3 escolas.. Fonte: a autora....40

Figura 16: Gráfico de barras dos alunos que possuem nenhum entendimento sobre poder de compra nas 3 escolas. Fonte: a autora....41

Figura 17: Ficha da atividade 2.1 - Orçamento Familiar. Fonte: a autora.

Figura 18: Ficha da atividade 2.2 - Orçamento Familiar. Fonte: a autora.

Figura 19: Exercício 3.1 da atividade 3 - Desconto e aumento. Fonte: a autora.

Figura 20: Exercício 3.2 da atividade 3 - juros. Fonte: a autora. 47

Figura 21: Exercícios 3.3 e 3.4 da atividade 3 - juros simples. Fonte: a autora.

Figura 22: Exercício 3.5 - juros compostos. Fonte: a autora. .48 


\section{Lista de Tabelas}

Tabela 1: Evolução dos Juros do exmplo 5. Fonte: A autora. ...................31

Tabela 2: Evolução do Montante com Juros Compostos. Fonte : A autora.

.32

Tabela 3: Resolução do Exemplo 6. Fonte: A autora..............................32 


\section{Lista de Quadros}

Quadro 1: Quadro de Índices, cesta de produtos e sua influência no setor financeiro. Fonte a autora.......................................................................24

Quadro 2: Informações de Unidades, Conhecimentos e Habilidades sobre Matemática Financeira conforme BNCC. Fonte: MEC - Brasil ................29 


\section{Lista de Siglas}

AEF - Brasil - Associação de Educação Financeira de Brasil

B3 - Brasil, Bolsa, Balcão

BACEN - Banco Central do Brasil

BNCC - Base Nacional Curricular Comum

CEMBC - Colégio Estadual Monsenhor Barenco Coelho

CNC - Confederação Nacional do Comércio de Bens, Serviços e Turismo

CONEF - Comitê Nacional de Educação Financeira

CVM - Comissão de Valores Mobiliários

EMLG - Escola Municipal Luiz Gonzaga

EMPADC - Escola Municipal Professora Aurelina Dias Cavalcanti

ENEF - Estratégia Nacional de Educação Financeira

OCDE - Organização para Cooperação e Desenvolvimento Econômico

PREVIC - Superintendência Nacional de Previdência Complementar

SEEDUC RJ - Secretaria de Educação do Estado do Rio de Janeiro

SEMED SG-Secretaria Municipal de Educação de São Gonçalo 


\section{1. Introdução}

Em janeiro de 2020, foi divulgado pela Confederação Nacional do Comércio de Bens, Serviços e Turismo (CNC) dados de uma pesquisa onde indicava que mais de $65 \%$ dos brasileiros estão endividados. Essa situação resulta das diversas instabilidades econômicas que o Brasil vem enfrentando ao longo dos últimos anos. As reformas trabalhista e previdenciária foram aprovadas na expectativa de que pudessem trazer um certo equilíbrio fiscal e que houvesse uma retomada dos investimentos e empregos, no entanto fomos arrebatados por uma crise sanitária de proporção mundial tornando-se um grande balde de água fria numa economia que começava a dar leves sinais de recuperação.

Diante de um contexto econômico como esse tornou-se essencial falarmos sobre Educação Financeira, que já se mostrava um tema relevante por ser uma política de Estado de caráter permanente através da Estratégia Nacional de Educação Financeira (ENEF), instituída inicialmente pelo Decreto Federal 7.397/2010, e que passou a ser tema transversal obrigatório segundo a Base Nacional Comum Curricular (BNCC), homologada em 2017 para o Ensino Fundamental e em 2018 para o Ensino Médio.

A obrigatoriedade de tratar desse tema nas grades curriculares pode gerar um impacto muito positivo para essa geração que em breve se tornará economicamente ativa, pois a falta da educação financeira contribui para o endividamento das famílias brasileiras como aponta Tolotti:

"Os especialistas apontam como principais causas do endividamento da população a falta de educação financeira, o consumo excessivo e, por último, os baixos rendimentos. Mas é possível avançar nesse entendimento e acrescentar as causas efetivas que, em alguns casos, são as mais determinantes na contração das dívidas" (TOLOTTI, 2007).

Para Silva e Bezerra (2016) é na escola que o educando desde cedo, através da educação financeira, poderá entender e conhecer suas responsabilidades e terá suporte necessário para compreensão do tema, levando as questões para também 
serem discutidas no âmbito familiar. Nesse sentindo, Cerbasi (2009) também acredita que os jovens devem participar do contexto financeiro familiar:

"O envolvimento dos filhos na construção e no controle do orçamento doméstico deve ser encorajado. Essa é uma forma bastante eficiente de praticar a educação financeira em casa, pois estimula os filhos a adotarem decisões financeiras mais maduras" (CERBASI, 2009)

Com o objetivo de despertar nos alunos a curiosidade pela educação financeira para que eles construam os conhecimentos necessários, através da matemática financeira, para a tomada consciente de decisões relacionadas ao consumo e seu planejamento financeiro individual estruturamos o presente trabalho em 5 capítulos.

O primeiro capítulo é esta introdução onde apresentamos as justificativas e objetivos da pesquisa.

No segundo capítulo, trazemos o conceito de Educação financeira segundo a Organização para Cooperação e Desenvolvimento Econômico (OCDE), e fazemos uma breve apresentação da Estratégia Nacional de Educação Financeira (ENEF) que é a legitimação no direito positivado da importância da educação financeira como medida de políticas públicas. E encerramos o segundo capítulo com documento da Base Nacional Comum Curricular (BNCC), que incluiu a educação financeira como tema transversal entre as disciplinas.

No terceiro capítulo abordamos conceitos econômicos relevantes para o letramento financeiro de todo indivíduo, tais como inflação, poder de compra, taxa básica de juros e tipos de crédito, além de conceitos de matemática financeira que dão suporte para tomada de decisão correta acerca de questões financeiras.

No quarto capítulo apresentamos os resultados obtidos com aplicação das atividades nas turmas de $8^{\circ}$ ano e $9^{\circ}$ ano, onde observamos inicialmente o baixo grau de conhecimento acerca dos conceitos econômicos, porém após as devidas explicações avaliamos que os alunos conseguiram resolver as questões propostas.

No quinto capítulo fazemos nossas considerações finais a respeito da importância de contextualizar a matemática financeira, conectando-a às práticas e vivências dos discentes, despertando neles o interesse pela educação financeira. 


\section{2.}

\section{A Educação Financeira}

Neste capítulo vamos abordar os conceitos que norteiam a Educação Financeira - EF, como ela foi formalizada no Brasil através da Estratégia Nacional de Educação Financeira (ENEF) e sua obrigatoriedade na Base Nacional Comum Curricular (BNCC).

\subsection{O que é Educação Financeira?}

Com o desenvolvimento da sociedade as relações econômicas tornaram-se mais variadas e isso gerou mais dificuldade para que os indivíduos sejam capazes de fazer opções de consumo responsável e consciente. Nesse cenário, a educação financeira vem ganhando protagonismo por oferecer ferramentas que formam o cidadão apto a tomar decisões autônomas de consumo e poupança equilibrados para o planejamento de sua vida financeira no curto, médio e longo prazo.

O ensino de tópicos financeiros que norteiam a tomada de decisão da população pode surgir com os mais diversos nomes, tais como, matemática comercial, ensino básico de finanças, matemática financeira, finanças pessoais, educação financeira, ou ainda, inteligência financeira. Para a Organização para Cooperação e Desenvolvimento Econômico (OCDE, 2005), educação financeira é:

"O processo em que os indivíduos melhoram a sua compreensão sobre os produtos financeiros, seus conceitos e riscos, de maneira que, com informação e recomendação claras, possam desenvolver as habilidades e a confiança necessárias para tomarem decisões fundamentadas e com segurança, melhorando o seu bem-estar financeiro" (OCDE, 2005)

Para Saito (2008), a educação financeira não tem por objetivo único o acúmulo exclusivo de dinheiro por parte do indivíduo, mas a sua integralização na sociedade por meio de suas atitudes pró-ativas que visam seu bem-estar.

Podemos perceber que educar financeiramente um aluno é muito mais que ensinar sobre matemática financeira, embora ela seja um tema central e imprescindível. Segundo Muniz (2013):

"educar financeiramente é uma ação muito mais ampla, que deve incluir: aprender matemática para compreender as situações 
financeiras; entender o comportamento do dinheiro no tempo; organizar conscientemente suas finanças (futuras) pessoais; discutir matematicamente o uso consciente do crédito; entender temas de economia como PIB, inflação e seus diferentes índices, IOF, IR dentre outros; aprender, interligar e utilizar matemática financeira nas questões geoeconômicas já abordadas, porém não interligadas, nas aulas de Geografia; compreender os principais sistemas de financiamentos (PRICE e SAC), utilizando os recursos tecnológicos amplamente disponíveis, como planilhas eletrônicas e calculadoras científicas; refletir e analisar matematicamente o aumento da expectativa de vida do brasileiro e seus impactos na economia nacional, incluindo sua própria aposentadoria, seguros em geral e previdência complementar; discutir e analisar quantitativa e qualitativamente os impactos de problemas geopolíticos e sociais nas economias de uma região, levando-se em consideração a viabilidade das ferramentas matemáticas estudadas, dentre outros." (MUNIZ, 2013)

Percebemos então, que a matemática financeira integra a educação financeira com a otimização de escolhas formando indivíduos capazes de consumir com qualidade e consciência, munidos de técnicas e ferramentas lógicas que os auxiliarão a alcançar objetivos financeiros atravessando os diferentes cenários econômicos.

\subsection{Estratégia Nacional de Educação Financeira - ENEF}

Hoje a educação financeira está bem difundida como um tema presente nos mais diversos meios de comunicação, mas essa frequência nas mídias e nos lares brasileiros é algo recente e ainda não se traduz em realidade no tange a aplicação prática das teorias que englobam o tópico.

Em 2010 houve uma formalização desse tema na legislação brasileira, por meio do decreto federal de $n^{\circ} 7397 / 2010$ que instituiu como política de Estado de caráter permanente a Estratégia Nacional de Educação Financeira (ENEF - Fig.1). A iniciativa, que conta com o apoio de vários ministérios, institutos e órgãos, e juntos formavam o Comitê Nacional de Educação Financeira - CONEF, tem por objetivo originário fortalecer a cidadania apoiando e fornecendo ações permitam tomadas de decisões financeiras mais conscientes e autônomas por parte da população brasileira. 


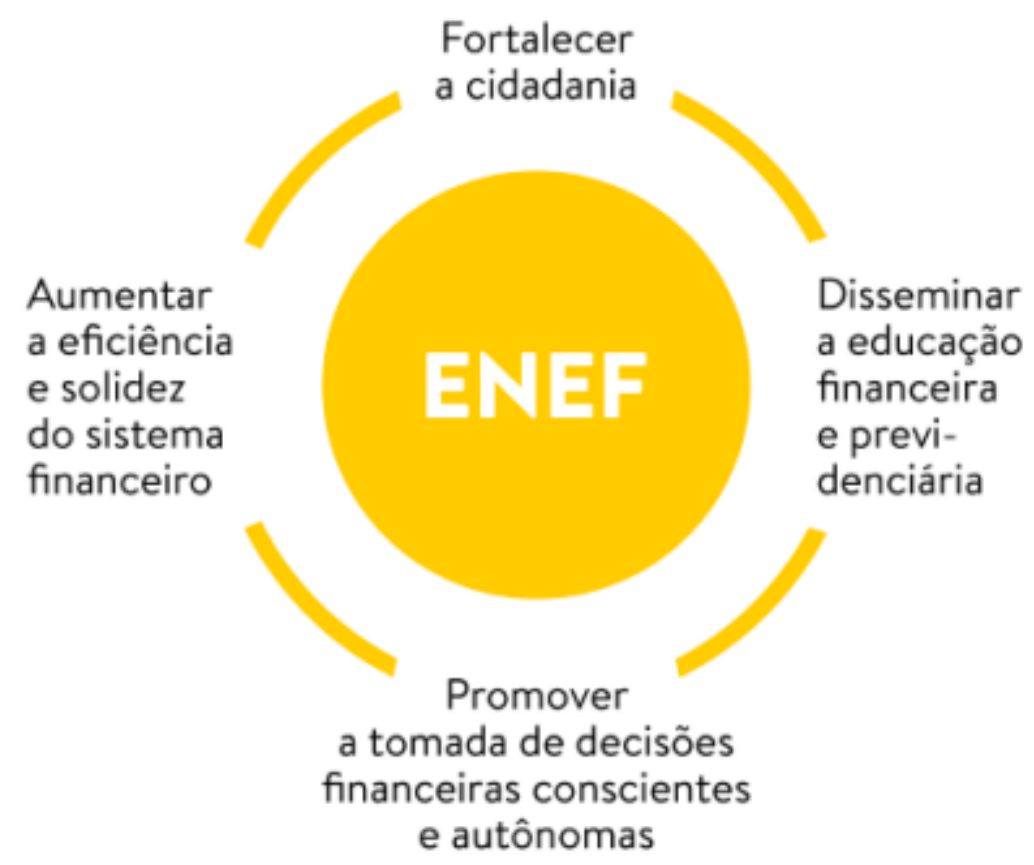

Figura 1: Finalidade da ENEF segundo decreto no 7397 de 2010. Fonte: BRASIL, Infográfico ENEF.

As ações da ENEF são compostas por programas transversais, coordenados pela Associação de Educação Financeira de Brasil (AEF-Brasil) e programas setoriais desenvolvidos pelos membros do CONEF. Dos programas transversais, dois merecem destaque e relevância para o presente trabalho, são eles: Programa Educação Financeira nas Escolas e o Programa de Educação Financeira de Adultos.

O ambiente escolar, por ser um local em que crianças e jovens desenvolvem e aprimoram diversas habilidades que terão impacto direto em suas realizações e conquistas, torna-se o sítio ideal para o desenvolvimento da EF como um tema multidisciplinar para o Ensino Fundamental e Médio abordando conteúdos que influencie o tempo presente e o futuro. A ENEF sugere que a educação financeira nas escolas seja abordada segundo as dimensões espacial e temporal.

A dimensão espacial abrange os níveis individual, local, regional, nacional e global tratando os conceitos que sejam consequências das ações individuais inseridas sob o contexto social do indivíduo. A dimensão temporal aborda as temáticas indicando que as escolhas feitas no presente podem afetar o futuro gerando uma conexão entre passado, presente e futuro, conforme figura 2 a seguir. 


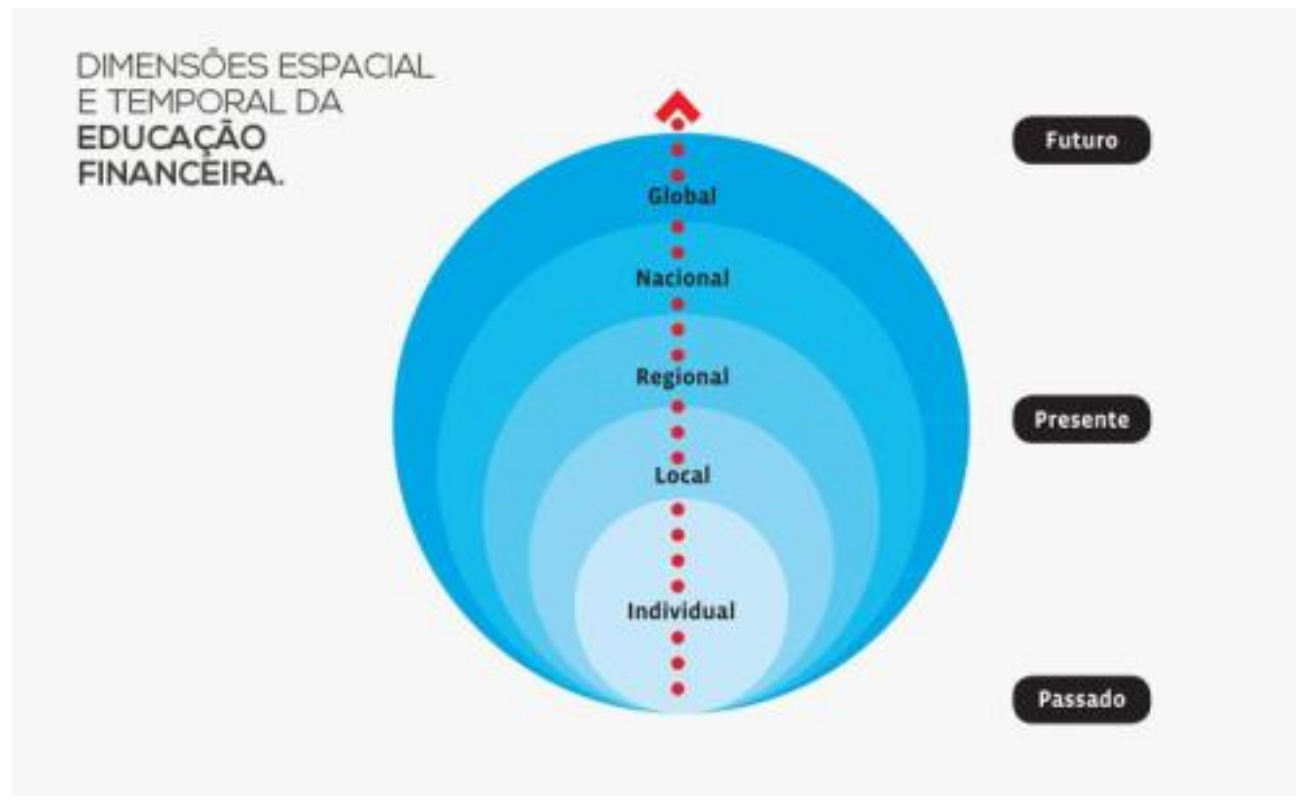

Figura 2: Dimensão temporal e espacial da Educação Financeira. Fonte: BRASIL. Programa de Educação Financeira nas Escolas: Modelo Conceitual e Objetivos. 2016

A partir desses conceitos, que foram definidos no Plano Diretor da ENEF, a AEF-Brasil elaborou o projeto pedagógico e dois módulos (professor e aluno) de livros para cada uma das séries letivas de cada etapa de ensino que permitem a simulações de situações cotidianas adequando sua linguagem à faixa etária dos alunos, inserindo o assim o tema nas práticas educacionais.

O Programa Educação Financeira na Escolas teve origem no Ensino Médio, com um projeto piloto aplicado em 891 escolas, todas da rede pública de ensino, de 2010 a 2011. Os livros (Fig. 03) encontram-se disponíveis para leitura ou download em https://www.vidaedinheiro.gov.br/livros-ensino-medio/.

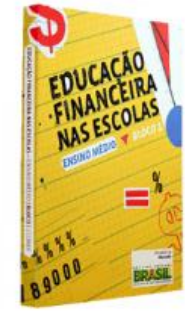

Livro 1

Você Aqui e Agora

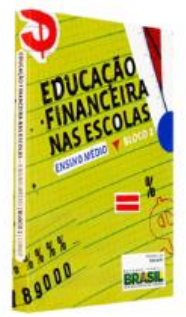

Livro 2

Você Seu Futuro

Fazendo Acontecer!

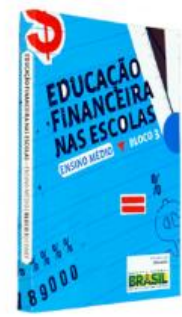

Livro 3

Você Eu, Nós No Mundo!

Figura 3: Programa Educação Financeira na Escolas - Livros para Ensino Médio. Fonte: disponíveis em <https://www.vidaedinheiro.gov.br/livros-ensino-medio/> 
Em 2014 foi concluído o conjunto de livros para o Ensino fundamental, com o apoio da BM\&FBOVESPA, atual B3 - Brasil, Bolsa e Balcão, integrando os conteúdos formais aos conteúdos sociais. O projeto piloto foi aplicado em 200 escolas da rede pública de Manaus/AM e Joinville/SC e teve uma avaliação do Banco Mundial cujos resultados sugerem que o programa teve um impacto positivo no conhecimento financeiro e nas atitudes relacionadas às decisões de consumo e poupança. Os livros (Fig.4) para o Ensino Fundamental estão disponíveis em https://www.vidaedinheiro.gov.br/livros-ensino-fundamental/.
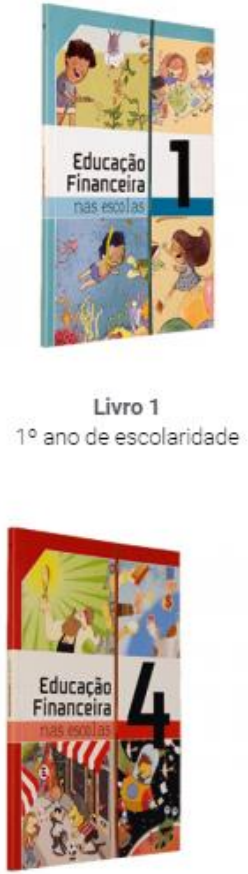

$$
\begin{gathered}
\text { Livro } 4 \\
4^{\circ} \text { ano de escolaridade }
\end{gathered}
$$

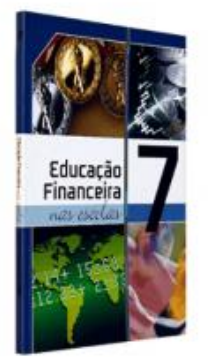

Livro 7

$7^{\circ}$ ano de escolaridade

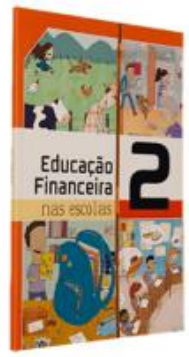$$
\begin{gathered}
\text { Livro } 2 \\
2^{\circ} \text { ano de escolaridade }
\end{gathered}
$$

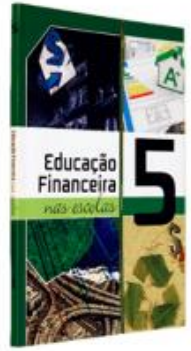

$$
\begin{gathered}
\text { Livro } 5 \\
5^{\circ} \text { ano de escolaridade }
\end{gathered}
$$
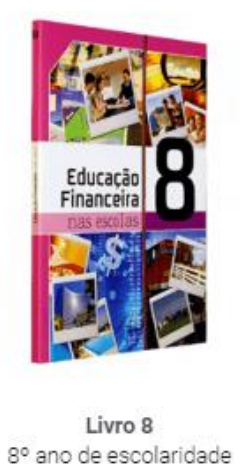

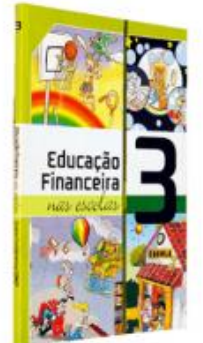

$$
\begin{gathered}
\text { Livro } 3 \\
3^{\circ} \text { ano de escolaridade }
\end{gathered}
$$

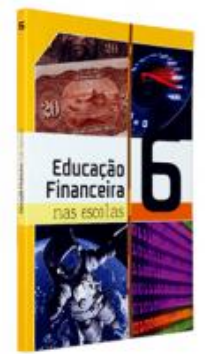

$$
6^{\circ} \text { ano de escolaridade }
$$

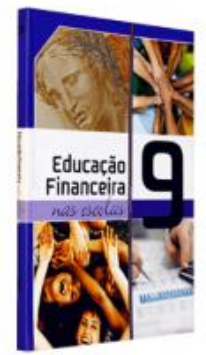

Livro 9

$9^{\circ}$ ano de escolaridade - Modelos Pedagógicos

Figura 4: Conjunto de livros para o Ensino Fundamenta criados com o apoio da B3 (Brasil, Bolsa e Balcão). Fonte: < https://www.vidaedinheiro.gov.br/livros-ensino-fundamental/> 
Para os indivíduos adultos, que já são economicamente ativos, existe o Programa Educação Financeira de Adultos. Esta ação tem como público-alvo prioritário duas parcelas da população que são identificadas em situação de vulnerabilidade, são elas: mulheres beneficiárias do programa Bolsa Família e aposentados cuja renda varie de 1 a 2 salários mínimos (Brasil, 2010). Para o primeiro grupo foi pensado o programa "Futuro nas Mãos" e para o segundo foi elaborado o programa "Eu e Minha Aposentadoria", ambos oferecido em Centros de Referência de Assistência Social - CRAS.

Atingir esses adultos é particularmente desafiador, pois, em regra, eles não estão integrados a um sistema regular de ensino, o que torna mais difícil o acesso as informações e capacitações no tema de EF. Ainda pesa sobre esse desafio os hábitos e valores adquiridos ao longo dos anos que ficam enraizados dificultando mudança em relação a administração de seu próprio dinheiro e consumo consciente.

Para atingir o objetivo de melhorar a EF de adultos a ENEF oferece um conjunto de tecnologias sociais em seu site, que pode ser usada por qualquer organização pública ou privada.

Cabe ressaltar que para contextualização do presente trabalho, a revogação do decreto $\mathrm{n}^{\circ} 7.397$ de 2010 pelo decreto $\mathrm{n}^{\circ} 10.393$ de 2020 que institui a Nova ENEF e cria o Fórum Brasileiro de Educação Financeira - FBEF ainda não apresentam mudanças na abordagem dos temas ou programas de EF.

\subsection{Educação Financeira e a Base Nacional Comum Curricular - BNCC}

A Constituição Federal de 1988, no caput de seu artigo 210, versa que: "Serão fixados conteúdos mínimos para o ensino fundamental, de maneira a assegurar formação básica comum e respeito aos valores culturais e artísticos, nacionais e regionais."

Dessa forma, surge a necessidade de ser regulamentado um currículo que sirva de base comum a todos os entes federativos. Para a elaboração desse documento aconteceram várias ações colaborativas com professores, gestores, especialistas e também uma consulta pública, que ficou aberta à participação da sociedade brasileira contando com mais de 12 milhões de contribuições. 
Após todas essas iniciativas, o MEC, em 2017 entregou a versão final da Base Nacional Comum Curricular ao Conselho Nacional de Educação (CNE). O texto para Ensino Fundamental foi homologado no mesmo ano, e para o Ensino Médio em 2018. O documento trouxe a Educação Financeira como tema obrigatório figurando de forma transversal entre as disciplinas, deixando de ser um tópico abordado somente em matemática. Por exemplo em história é possível relacionar conceitos de inflação e poder de compra com as várias mudanças de moedas que tivemos no Brasil, ou ainda em ciências podemos mostrar como o consumo consciente e as preocupações com impactos ambientais interferem no desempenho financeiro das empresas.

Espera-se que com a obrigatoriedade do ensino de Educação Financeira os brasileiros que ainda vão se tornar economicamente ativos possam ter mais ferramentas para administrar seus recursos de maneira consciente e sustentável. As instituições de ensino tiveram até o ano de 2019 para adequar seus currículos à nova determinação. 


\section{3. \\ Matemática Financeira}

Neste capítulo iremos abordar temas e termos que estão comumente presentes nos livros didáticos sobre Matemática Financeira e nos noticiários econômicos.

\subsection{Conceitos Econômicos}

\subsubsection{Inflação e Deflação}

A inflação é um índice que mede o aumento dos preços de uma cesta de produtos e serviços. Para que esse índice seja representativo é preciso que essa cesta de produtos retrate os padrões de consumo da população em geral, por isso existem variados índices de inflação medidos por diversos institutos.

A deflação é o processo inverso da inflação, isto é, existe deflação quando os preços perdem valor e caem. Analisando somente pelo aspecto financeiro individual, as pessoas tendem a acreditar que quando ocorre deflação é bom, pois as coisas ficam "mais baratas". No entanto, quando olhamos para economia, a queda persistente e generalizada dos preços é tão ruim ou pior que uma hiperinflação. Quando ocorre o fenômeno da deflação, em geral, é por consequência de uma recessão ou excesso de oferta sem demanda.

No Brasil temos duas instituições que se destacam quando avaliamos o índice de variação dos preços, a primeira delas é o Instituto Brasileiro de Geografia e Estatística - IBGE que mede o IPCA (Índice de Preço ao Consumidor Amplo), a segunda é a Fundação Getúlio Vargas - FGV que mede IGP-M (Índice Geral de Preços de Mercado) e o IGP-DI (Índice Geral de Preços - Disponibilidade Interna). No quadro 1 a seguir, podemos observar um resumo desses três índices. 
Quadro 1: Quadro de Índices, cesta de produtos e sua influência no setor financeiro. Fonte: Valor Investe < $<$ ttps://valorinveste.globo.com/mercados/brasil-epolitica/noticia/2019/05/03/ipca-igp-m-inpc-qual-a-inflacao-verdadeira.ghtml>.

\begin{tabular}{|c|c|c|c|c|}
\hline ÍNDICE & PERIODICIDADE & $\begin{array}{l}\text { INSTITUIÇÃO } \\
\text { RESPONSÁVEL }\end{array}$ & QUAL A CESTA DE PRODUTOS? & INFLUÊNCIA \\
\hline $\begin{array}{c}\text { IPCA - Índice de } \\
\text { Preço ao Consumidor } \\
\text { Amplo }\end{array}$ & MENSAL & IBGE & $\begin{array}{l}\text { Os } 400 \text { itens mais consumidos por famílias com } \\
\text { renda mensal entre } 1 \text { e } 40 \text { salários mínimos, de } \\
\text { Belém, Fortaleza, Recife, Salvador, Belo } \\
\text { Horizonte, Rio de Janeiro, Vitória, São Paulo, } \\
\text { Curitiba, Porto Alegre, Brasília, Goiânia e Campo } \\
\text { Grande. }\end{array}$ & $\begin{array}{c}\text { Afeta o rendimento dos seguintes títulos } \\
\text { públicos: Tesouro IPCA+ (NTN-B Principal) e } \\
\text { IPCA com juros semestrais (NTN-B). Na renda } \\
\text { fixa, há opções pós-fixadas, como letras de } \\
\text { crédito, que pagam o CDI mais o IPCA do } \\
\text { período. }\end{array}$ \\
\hline $\begin{array}{l}\text { IGP-M - Índice Geral } \\
\text { de Preços do Mercado }\end{array}$ & MENSAL & FGV & $\begin{array}{c}\text { Observa preços no atacado para produtores }(60 \% \\
\text { do índice) e no varejo para consumidores }(30 \%) \text { e } \\
\text { construção civil }(10 \%) \text {. }\end{array}$ & $\begin{array}{c}\text { É a principal referência para o reajuste de } \\
\text { alugueis e tarifas públicas, como energia elétrica. } \\
\text { Fundos imobiliários também remuneram com } \\
\text { base no índice. }\end{array}$ \\
\hline $\begin{array}{l}\text { IGP-DI - Índice Geral } \\
\text { de Preços - } \\
\text { Disponibilidade } \\
\text { Interna }\end{array}$ & MENSAL & FGV & $\begin{array}{l}\text { Mesma metodologia do IGP-M. A diferença é } \\
\text { que, enquanto IGP-M registra o movimento } \\
\text { médio dos preços em } 30 \text { dias fechados, IGP-DI } \\
\text { mede de um dia } 21 \text { ao outro. }\end{array}$ & $\begin{array}{l}\text { Também utilizado para o reajuste de alugueis e } \\
\text { tarifas públicas. }\end{array}$ \\
\hline
\end{tabular}




\subsubsection{Poder de Compra}

Uma vez que se tem o entendimento claro do que é a inflação, podemos falar do poder de compra, que de forma bem simples é a capacidade de adquirir bens e serviços com uma determinada quantidade de dinheiro. A variação dos preços e o poder de compra estão intimamente ligados, assim se existe uma inflação descontrolada a consequência é que diminui a nossa capacidade de obter produtos.

O poder de compra é calculado em vários países por diversas instituições e segundo REIS (2019), um índice utilizado para comparar o poder de compra de países distintos é relacionar o preço do "Big Mac" com o salário mínimo daquele local. O índice "Big Mac", organizado pela revista "The Economist", consegue indicar de forma simples o poder de compra de uma nação e a valorização/desvalorização de sua moeda frente ao dólar, uma vez que o sanduíche da rede de franquias é produzido com os mesmos ingredientes em uma centena de países.

\subsubsection{Taxa Selic}

A partir da necessidade de angariar recursos o governo toma um empréstimo de forma indireta através da oferta de títulos do Tesouro Nacional, onde o governo devolverá ao comprador do título o valor pago acrescido de juros em uma data previamente determinada. A taxa Selic se relaciona aos juros desses títulos públicos oferecidos no Sistema Especial de Liquidação e Custódia - SELIC. Ela é a taxa básica de juros na economia brasileira.

O valor da Selic que é amplamente divulgado nos noticiários é a chamada Selic Meta, determinada pelo Comitê de Política Monetária - COPOM, cujos membros se reúnem periodicamente e definem meta anual da taxa. Ela costuma ser a menor taxa de juros do mercado.

A taxa real praticada no mercado é a Selic Over, que é definida diariamente resultante da média ponderada de todas as operações realizadas com títulos públicos no sistema SELIC. A taxa "overnight" decorre da negociação dos bancos entre si, 
usando os títulos públicos que compraram como garantia, e tendem a ser ligeiramente menores que a Selic Meta.

A taxa Selic tem influência direta em muitas aplicações, inclusive na mais popular entre os brasileiros, a poupança, que em 2012 teve alterada sua regra de remuneração, conforme Fig.05 abaixo, passando a vigorar da seguinte forma: caso a Selic seja maior que $8,5 \%$ o rendimento é fixo de $6,17 \%$, se for menor ou igual a 8,5\% rende $70 \%$ da Selic, em ambos os casos acrescido da Taxa Referencial - TR, que está zerada desde 2017 (BACEN). Hoje, com a Selic em 2,25\% ao ano, temos um rendimento anual da poupança de $1,56 \%$ ao ano, isto equivale a $0,13 \%$ ao mês,

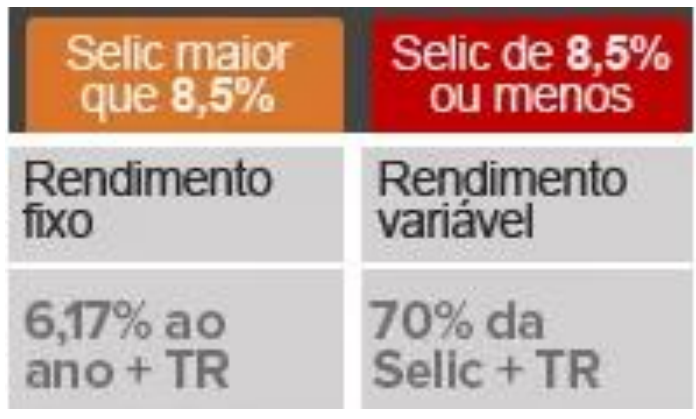

Figura 5: Comparativo entre os rendimentos da poupança, antes e depois da mudança de 2012. Fonte: Site G1 < http://g1.globo.com/economia/seu-dinheiro/noticia/2012/05/veja-perguntas-erespostas-sobre-mudancas-na-poupanca.html $>$

Além de servir de base remuneratória para diversas aplicações, a Selic também é usada como mecanismo de controle inflacionário, quando os índices de inflação sobem o COPOM aumenta a taxa básica. Dessa forma o crédito fica mais caro, diminuindo o consumo e forçando uma queda nos preços. Quando a economia está com sua inflação controlada, dentro da meta, e a demanda está reduzida, é comum abaixar o valor da taxa Selic para estimular o consumo por meio de um crédito mais barato.

\subsubsection{Crédito e Custo efetivo Total (CET)}

Segundo o dicionário online Michaelis, a palavra crédito, tem etimologia no latim 'creditus', e significa na linguagem comercial:

"Bem, serviço ou quantia em dinheiro postos à disposição de alguém por empresa, loja credora, estabelecimento bancário, financeira etc., mediante quaisquer tipos de provas (carnês, letras de câmbio, notas promissórias e 
outros) que configuram a oficialização de um compromisso de pagamento futuro." (MICAHELIS)

Essa disposição de recursos encontra-se no mercado em três modalidades de operações de créditos distintas, conforme circular nº1273 do BACEN, são elas:

a) empréstimos - são as operações realizadas sem destinação específica ou vínculo à comprovação da aplicação dos recursos.

b) financiamentos - são as operações realizadas com destinação específica, vinculadas à comprovação da aplicação dos recursos.

c) títulos descontados - são as operações de desconto de títulos; (usado por pessoas jurídicas)

Fazer uso de alguma modalidade de crédito não é uma atitude ruim quando se avalia corretamente qual o tipo de crédito é melhor para a ocasião e qual é o custo total efetivo - CET envolvido na operação. Isto é, quais são todas as taxas vinculadas à transação. De modo geral as pessoas se preocupam em saber quanto é a taxa de juros, mas esquecem que existem outras despesas que pesam sobre as operações, tais como registro de contrato, tributos, tarifas e outros.

Dessa forma, o BACEN por meio de sua resolução nº3517 determinou que o CET deve ser informado, na forma de taxa percentual anual, previamente à contratação do crédito.

\subsection{Conceitos Matemáticos}

\subsubsection{Porcentagem e Fator multiplicativo}

As taxas percentuais e o símbolo '\%” são amplamente utilizados no mundo financeiro, por isso sua compreensão é tão importante para qualquer tomada de decisão no âmbito financeiro. De maneira bem intuitiva, temos que toda fração centesimal é uma porcentagem, de modo que o denominador 100 deu lugar ao símbolo '\%'. Por exemplo 1:

$$
0,25=\frac{25}{100}=25 \%
$$

Mas variação percentual também pode advir de outras razões cujos denominadores não sejam necessariamente 100. Veja o exemplo 2: 
“Uma blusa custava $R \$ 50,00$ e teve $R \$ 10,00$ de desconto. Qual foi a taxa percentual de desconto?"

Para resolver esse tipo de problema podemos escrever a razão entre o desconto e o valor inicial da blusa para sabermos o quanto 10 representa de 50 . Dessa forma teríamos $\frac{10}{50}=0,2 \Rightarrow 0,2 \times 100=20 \%$. Então um desconto de 10 reais numa blusa que custava 50 reais, representa $20 \%$ de desconto.

Nesta mesma situação proposta no exemplo 2, poderíamos alterar os dados fornecidos e mudar a pergunta da seguinte forma, no exemplo 3:

"Uma blusa custava R\$50,00 e teve 20\% de desconto. Quanto passou a custar essa blusa?"

Nessa resolução podemos então descobrir quanto é $20 \%$ de 50 reais e em seguida efetuarmos uma subtração referente ao desconto, conforme os cálculos a seguir:

$$
\begin{aligned}
20 \%=\frac{20}{100} & \Rightarrow \frac{20}{100} \times 50=\frac{20 \times 50}{100}=\frac{1000}{100}=10 \\
50 & -10=40 \Rightarrow \text { A blusa passou a custar } \mathrm{R} \$ 40,00 .
\end{aligned}
$$

Essa é forma de resolver que podemos observar na maioria dos livros didáticos para o segundo segmento do Ensino Fundamental, mas seria mais prático fazermos a conta com o Fator Multiplicativo $(1+i)$ para aumento e $(1-i)$ para desconto, onde $i$ é taxa em sua representação decimal. Portanto, o problema anterior pode ser solucionado assim:

$$
20 \%=0,20 \Rightarrow \text { Valor da blusa }=50 \times(1-0,20)=50 \times 0,80=40 \text { reais }
$$

Podemos observar também como o fator multiplicativo pode facilitar a solução de situação-problemas que surgem cotidianamente para todos nós. Observemos mais um caso, exemplo 4:

"É comum nos restaurantes a indicação de uma taxa de serviço de $10 \%$ sobre o total consumido. Suponhamos que um casal consumiu um total de $R \$ 90,00$ e queira acrescentar a taxa de serviço ao pagamento da conta, qual seria o valor total a pagar?"

$$
10 \%=0,10 \Rightarrow \text { Total a pagar }=90 \times(1+0,10)=90 \times 1,10=99 \text { reais }
$$


Calcular aumentos ou descontos com os fatores multiplicativos $(1+i) \mathrm{e}$ $(1-i)$ pode ser ensinado desde o $6^{\circ}$ ano do Ensino Fundamental já que os números decimais e porcentagem são objetos de conhecimento dessa série escolar, conforme mostra o quadro 2 retirado da BNCC.

Quadro 2: Informações de Unidades, Conhecimentos e Habilidades sobre Matemática Financeira conforme BNCC. Fonte: BRASIL

$\langle$ http://basenacionalcomum.mec.gov.br/images/BNCC_EI_EF_110518_versaofinal_site.pdf 〉

\begin{tabular}{|c|c|c|}
\hline $\begin{array}{c}\text { Unidades } \\
\text { Temáticas }\end{array}$ & $\begin{array}{c}\text { Objetos de } \\
\text { Conhecimento }\end{array}$ & Habilidades \\
\hline \multirow{3}{*}{ Números } & $\begin{array}{l}\text { Sistema de numeração } \\
\text { decimal: características, } \\
\text { leitura, escrita e comparação } \\
\text { de números naturais e de } \\
\text { números racionais } \\
\text { representados na forma } \\
\text { decimal }\end{array}$ & $\begin{array}{l}\text { (EF06MA01) Comparar, ordenar, ler e } \\
\text { escrever números naturais e números racionais } \\
\text { cuja representação decimal é finita, fazendo } \\
\text { uso da reta numérica. } \\
\text { (EF06MA02) Reconhecer o sistema de } \\
\text { numeração decimal, como o que prevaleceu } \\
\text { no mundo ocidental, e destacar semelhanças e } \\
\text { diferenças com outros sistemas, de modo a } \\
\text { sistematizar suas principais características } \\
\text { (base, valor posicional e função do zero), } \\
\text { utilizando, inclusive, a composição e } \\
\text { decomposição de números naturais e números } \\
\text { racionais em sua representação decimal. }\end{array}$ \\
\hline & $\begin{array}{l}\text { Operações (adição, } \\
\text { subtração, multiplicação, } \\
\text { divisão e potenciação) com } \\
\text { números racionais }\end{array}$ & $\begin{array}{l}\text { (EF06MA11) Resolver e elaborar problemas } \\
\text { com números racionais positivos na } \\
\text { representação decimal, envolvendo as quatro } \\
\text { operações fundamentais e a potenciação, por } \\
\text { meio de estratégias diversas, utilizando } \\
\text { estimativas e arredondamentos para verificar a } \\
\text { razoabilidade de respostas, com e sem uso de } \\
\text { calculadora. }\end{array}$ \\
\hline & $\begin{array}{l}\text { Cálculo de porcentagens por } \\
\text { meio de estratégias diversas, } \\
\text { sem fazer uso da "regra de } \\
\text { três" }\end{array}$ & $\begin{array}{l}\text { (EF06MA13) Resolver e elaborar problemas } \\
\text { que envolvam porcentagens, com base na } \\
\text { ideia de proporcionalidade, sem fazer uso da } \\
\text { "regra de três", utilizando estratégias pessoais, } \\
\text { cálculo mental e calculadora, em contextos de } \\
\text { educação financeira, entre outros. }\end{array}$ \\
\hline
\end{tabular}




\subsubsection{Juros Simples e Compostos}

As operações financeiras quase sempre giram em torno do empréstimo de dinheiro. Seja quando queremos comprar algo cujo valor não temos naquele momento e recorremos a uma instituição para obtermos o dinheiro emprestado e pagarmos posteriormente, ou quando aplicamos nosso dinheiro em algum produto bancário que gere rendimento para ser resgatado futuramente. Nas duas situações, o juro é a remuneração que o tomador do empréstimo paga pelo "aluguel" do capital. Na Matemática financeira estudamos duas modalidades de juros, são eles: juros simples e juros compostos.

De modo geral, o mercado financeiro trabalha com juros compostos, porém existem alguns exemplos em que lidamos com os juros simples, como é o caso da multa de mora nos boletos bancários. O cálculo do juro simples incide sempre no capital inicial, dessa forma se tomarmos $i$ como a taxa percentual e $C$ como capital inicial temos que os juros $J$ é igual a $C$. $i$ para 1 período de tempo indicado pela taxa. Então para $n$ períodos, temos:

$$
J=C . i . n
$$

Considere o exemplo 5: "Qual seria o valor dos juros devidos num boleto vencido há 4 meses, cujo valor era de $R \$ 300,00$ e multa de mora de $2 \%$ ao mês (a.m.)?"

Nesta situação, segue que:

$$
\begin{gathered}
\text { Capital }=R \$ 300,00 ; \text { taxa }=2 \%=0,02 ; \text { tempo }=4 \text { meses } \\
J=C \cdot i \cdot n \\
J=300 \cdot 0,02 \cdot 4=24 \text { reais de juros. }
\end{gathered}
$$

Para sabermos o novo valor (Montante) do boleto basta somar os juros ao capital, dessa forma teremos $M=300+24=324$ reais. Generalizando, temos que o montante M é dado por:

$$
\begin{gathered}
M=C+J \\
M=C+C \cdot i \cdot n
\end{gathered}
$$




$$
M=C \cdot(1+i \cdot n)
$$

Esses conceitos podem ser aprofundados para alunos de $8^{\circ}$ e $9^{\circ}$ ano, uma vez que no $8^{\circ}$ ano eles começam a estudar equações lineares de $1^{\circ}$ grau fazendo associação a uma reta no plano cartesiano e no $9^{\circ}$ ano estudam funções como relações de dependência unívoca entre duas variáveis. Podemos representar graficamente a evolução dos juros para a situação exposta acima, no exemplo 5, através da tabela 1 e seu gráfico na figura 6.

Tabela 1: Evolução dos Juros do exeplo5. Fonte: A autora.

\begin{tabular}{cc}
\hline $\begin{array}{c}\text { Tempo de Atraso } \\
\text { (meses) }\end{array}$ & $\begin{array}{c}\text { Juros (em reais) } \\
J=C \cdot i \cdot n\end{array}$ \\
\hline 1 & 6,00 \\
2 & 12,00 \\
3 & 18,00 \\
4 & 24,00 \\
\hline
\end{tabular}

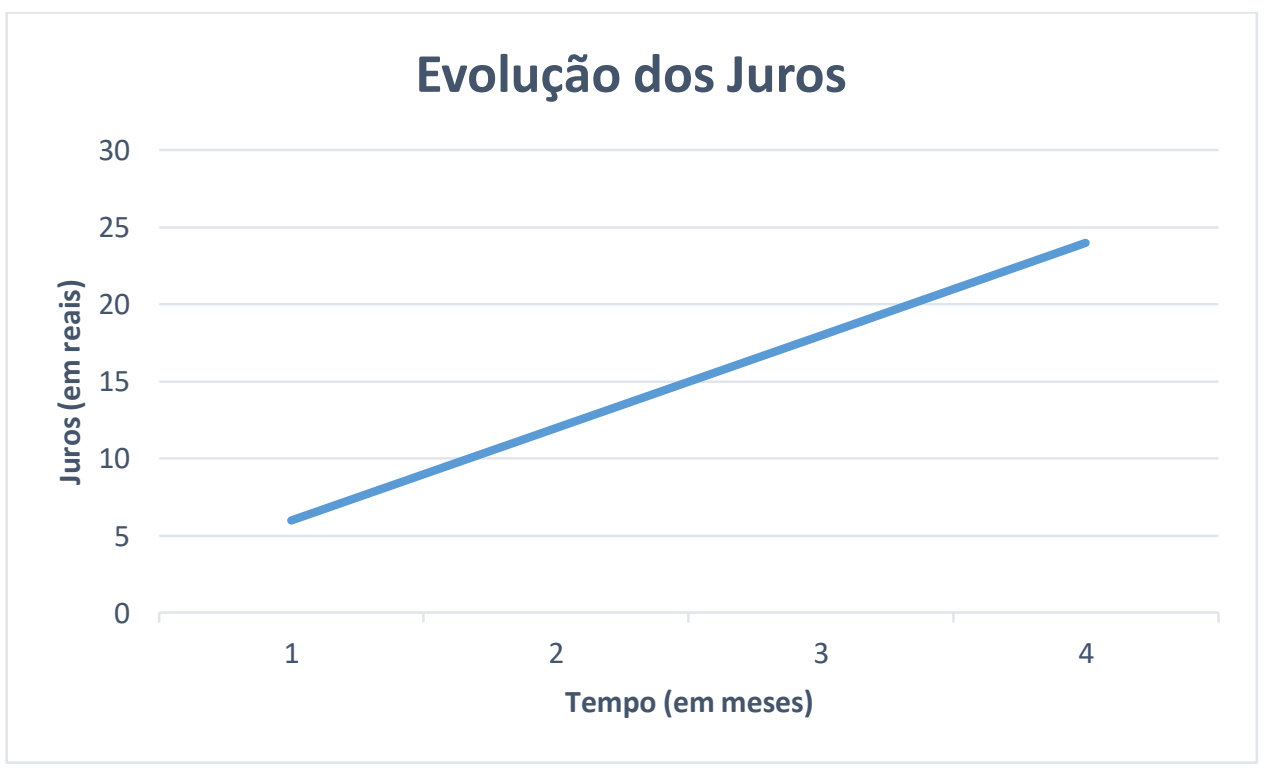

Figura 6: Gráfico demonstrando a evolução dos juros ao longo do tempo. Fonte: A autora. 
Note que o aumento é linear, isto é, constante. A cada mês que passa aumenta em 6 reais o valor devido, pois nos juros simples a taxa é calculada sobre a referência inicial. Nos juros compostos, já não ocorre dessa forma, nessa modalidade os juros são adicionados ao capital ao final de cada período, gerando um novo capital para incidência dos juros do próximo período, criando assim o que chamamos de juros sobre juros. Observe a evolução do montante nos juros compostos na tabela 2 .

Tabela 2: Evolução do Montante com Juros Compostos. Fonte: A autora.

\begin{tabular}{cc}
\hline Período & Montante \\
\hline 1 & $M_{1}=C+C \cdot i \Rightarrow M_{1}=C \cdot(1+i)$ \\
2 & $M_{2}=M_{1}+M_{1} \cdot i \Rightarrow M_{2}=M_{1} \cdot(1+i)$ \\
& $\Rightarrow M_{2}=C \cdot(1+i)^{2}$ \\
3 & $M_{3}=M_{2}+M_{2} \cdot i \Rightarrow M_{3}=M_{2} \cdot(1+i)$ \\
& $\Rightarrow M_{3}=C \cdot(1+i)^{3}$ \\
$\vdots$ & \\
$n$ & \\
&
\end{tabular}

Vamos analisar como seria a evolução do montante em um problema de capitalização a juros compostos. Veja o exemplo 6:

“João aplicou uma quantia de $R \$ 4000,00$ em um produto oferecido pelo banco que capitalizava 0,7\% ao mês por um período de 12 meses. Quanto João irá resgatar ao final da aplicação?"

Tabela 3: Resolução do Exemplo 6. Fonte: A autora.

\begin{tabular}{ccc}
\hline Meses & Juros & Montante \\
\hline 1 & $\mathrm{R} \$ 28,00$ & $\mathrm{R} \$ 4.028,00$ \\
2 & $\mathrm{R} \$ 28,20$ & $\mathrm{R} \$ 4.056,20$ \\
3 & $\mathrm{R} \$ 28,39$ & $\mathrm{R} \$ 4.084,59$ \\
4 & $\mathrm{R} \$ 28,59$ & $\mathrm{R} \$ 4.113,18$ \\
5 & $\mathrm{R} \$ 28,79$ & $\mathrm{R} \$ 4.141,97$
\end{tabular}




\begin{tabular}{ccc}
6 & $\mathrm{R} \$ 28,99$ & $\mathrm{R} \$ 4.170,97$ \\
7 & $\mathrm{R} \$ 29,20$ & $\mathrm{R} \$ 4.200,16$ \\
8 & $\mathrm{R} \$ 29,40$ & $\mathrm{R} \$ 4.229,57$ \\
9 & $\mathrm{R} \$ 29,61$ & $\mathrm{R} \$ 4.259,17$ \\
10 & $\mathrm{R} \$ 29,81$ & $\mathrm{R} \$ 4.288,99$ \\
11 & $\mathrm{R} \$ 30,02$ & $\mathrm{R} \$ 4.319,01$ \\
12 & $\mathrm{R} \$ 30,23$ & $\mathrm{R} \$ 4.349,24$ \\
\hline
\end{tabular}

Podemos perceber pela tabela 3, que ao final de 12 meses o valor resgatado por João será de $\mathrm{R} \$ 4.349,24$. Ao fazermos essa mesma análise para juros simples, teríamos: $\quad M=4000 \cdot(1+0,007 \cdot 12)=R \$ 4.336,00$. Concluímos que os rendimentos dos juros compostos geraram um montante maior que dos juros simples.

Embora o estudo de funções exponenciais não seja objeto de conhecimento matemático para o Ensino Fundamental, cabe mostrar graficamente a evolução do montante de cada regime de capitalização para que os alunos possam observar a velocidade de crescimento de uma função exponencial em relação a função linear, conforme a figura 7 .

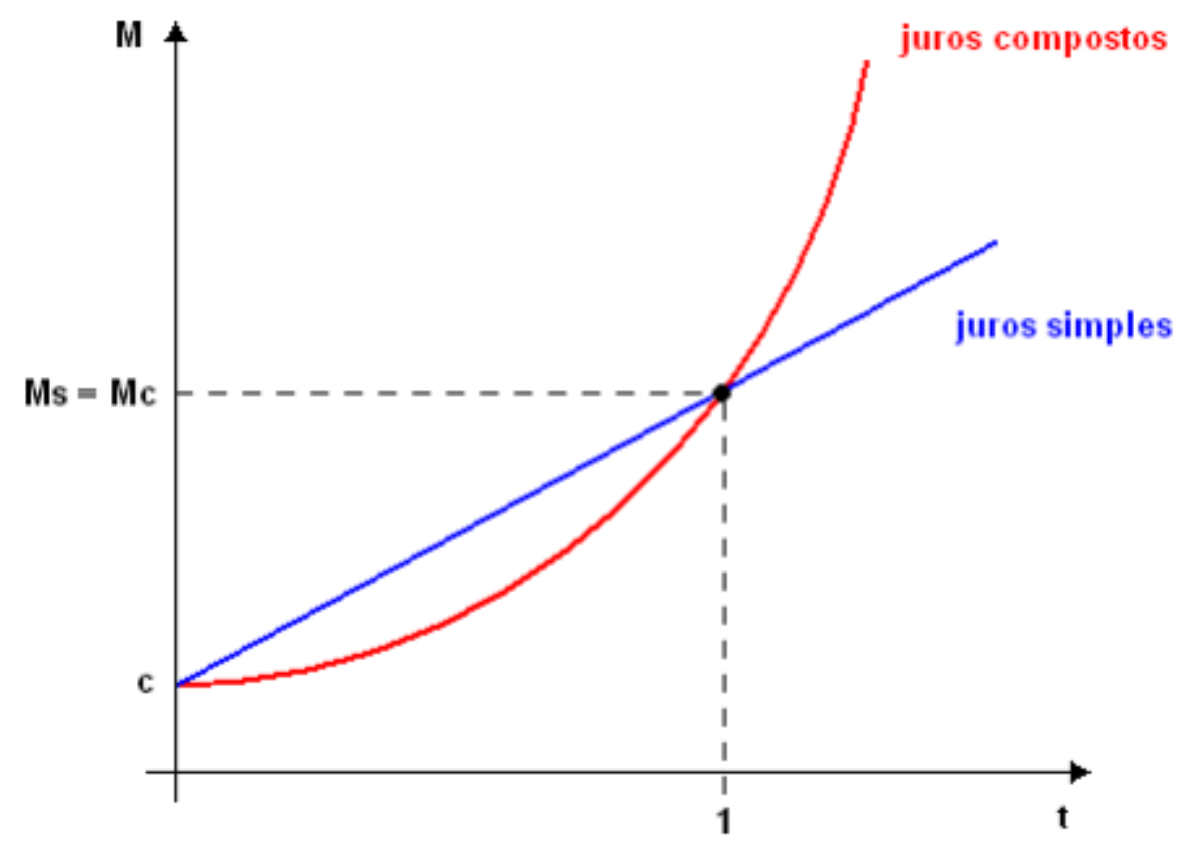

Figura 7: Gráfico comparativo entre um capital aplicado com juros simples e juros compostos. Fonte: ARAÚJO, Milton. Pílulas de Matemática Financeira (2). 2013. Disponível em: http://profmilton.blogspot.com.br/2013/12/pilulas-de-matematica-financeira-2.html. 


\section{4. Análise das Atividades Aplicadas em Sala}

Com intuito de contextualizar as teorias da matemática financeira com a realidade vivenciada pelos alunos, aplicamos algumas atividades que mostram a importância da educação financeira em face as situações do nosso cotidiano. As atividades propostas foram modificadas a partir dos trabalhos de Losano (2013), Guimarães (2018) e Muniz et al. (2018).

As atividades foram aplicadas entre fevereiro e março do ano letivo de 2020, em três escolas, duas da rede Municipal e uma da rede Estadual, todas localizadas no munícipio de São Gonçalo. As escolas municipais foram a Escola Municipal Luiz Gonzaga (EMLG), com uma turma de $9^{\circ}$ ano cuja listagem do diário constavam 42 alunos e uma turma de $8^{\circ}$ ano com 35 alunos, e Escola Municipal Professora Aurelina Dias (EMPAD), com duas turmas de $8^{\circ}$ ano, uma com 27 e outra com 25 alunos. E a escola estadual foi o Colégio Estadual Monsenhor Barenco Coelho (CEMBC), com três turmas de $9^{\circ}$ ano, a primeira com 41 alunos, a segunda com 31 e a terceira com 37 alunos, e uma turma de $8^{\circ}$ ano com 39 alunos.

\subsection{Atividade 1 - Questionário diagnóstico.}

A primeira proposta foi questionário aberto (anexo XX) com objetivo de entender os conceitos prévios dos alunos a respeito dos temas inflação/deflação e relação de poder compra. Abaixo segue cada uma das perguntas do questionário adaptado de Guimarães (2018) e em seguida iremos debater sobre os resultados obtidos a partir das respostas dos alunos. Através das respostas obtidas, classificamos o entendimento dos alunos acerca do tema em: Conhece, conhece pouco e desconhece. Consideramos que o aluno conhece quando traz uma explicação correta sobre o tema, avaliamos que conhece pouco quando a resposta está incompleta e/ou faltando elementos importantes sobre o conceito do tema e desconhece quando afirma nunca ter lido, ouvido ou estudado nada do tema.

A seguir temos os dados dos alunos que responderam às perguntas $\mathrm{A} e \mathrm{~B}$ da primeira atividade aplicada. A pergunta (A) era "O que você conhece sobre inflação?" e a pergunta (B) dizia "A inflação é um termo muito presente em 
noticiário econômicos, dessa forma o que você julga ser melhor para a economia de um país, uma inflação alta ou baixa? Por que? ". Na figura 8 podemos ver o percentual de alunos que conhecem o conceito de inflação nas três escolas. Na figura 9 temos o percentual dos alunos que conhecem pouco sobre inflação e na figura 10 representam os alunos que desconhecem do assunto.

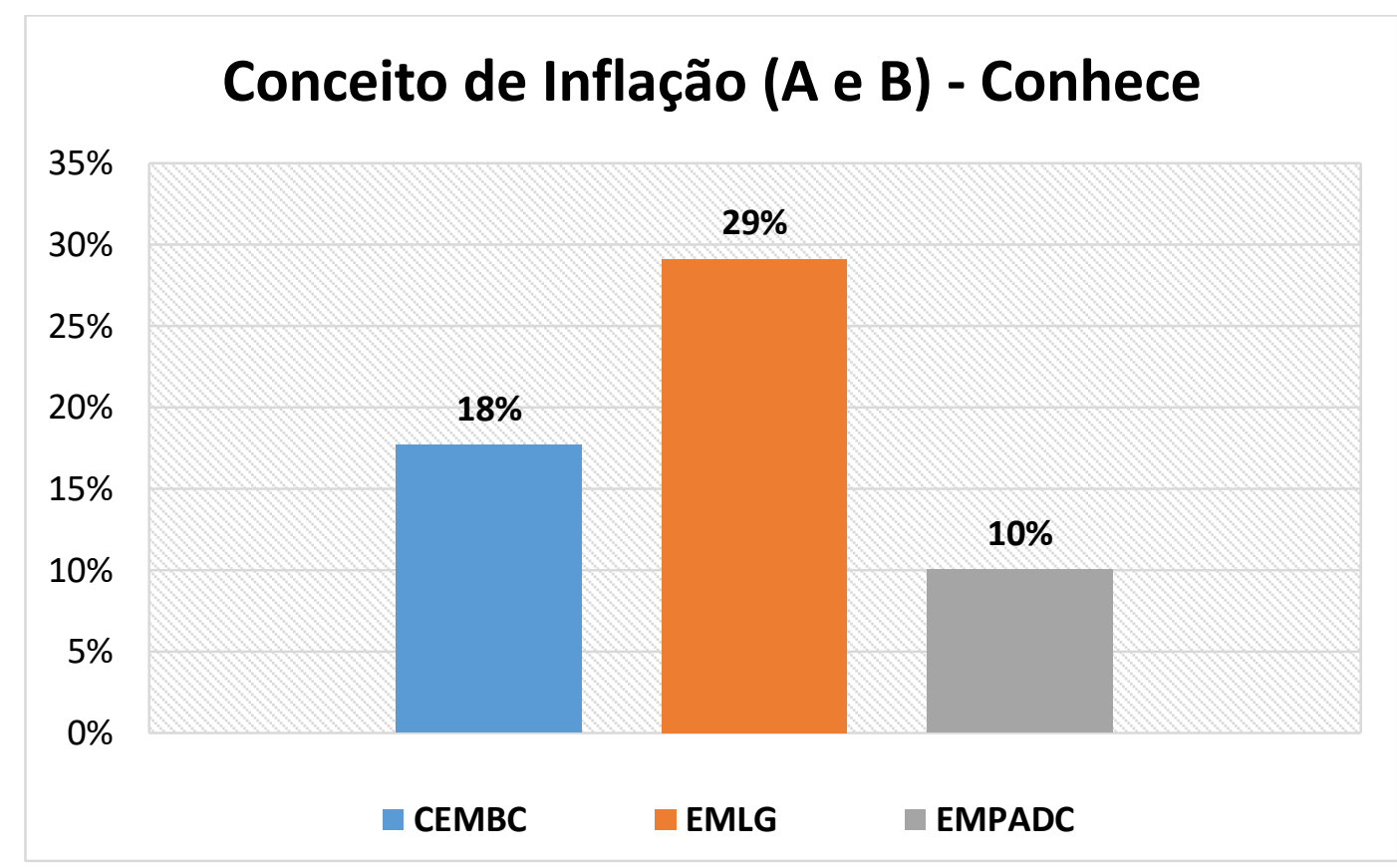

Figura 8: Gráfico de barras dos alunos que conhecem sobre inflação nas 3 escolas. Fonte: a autora. 


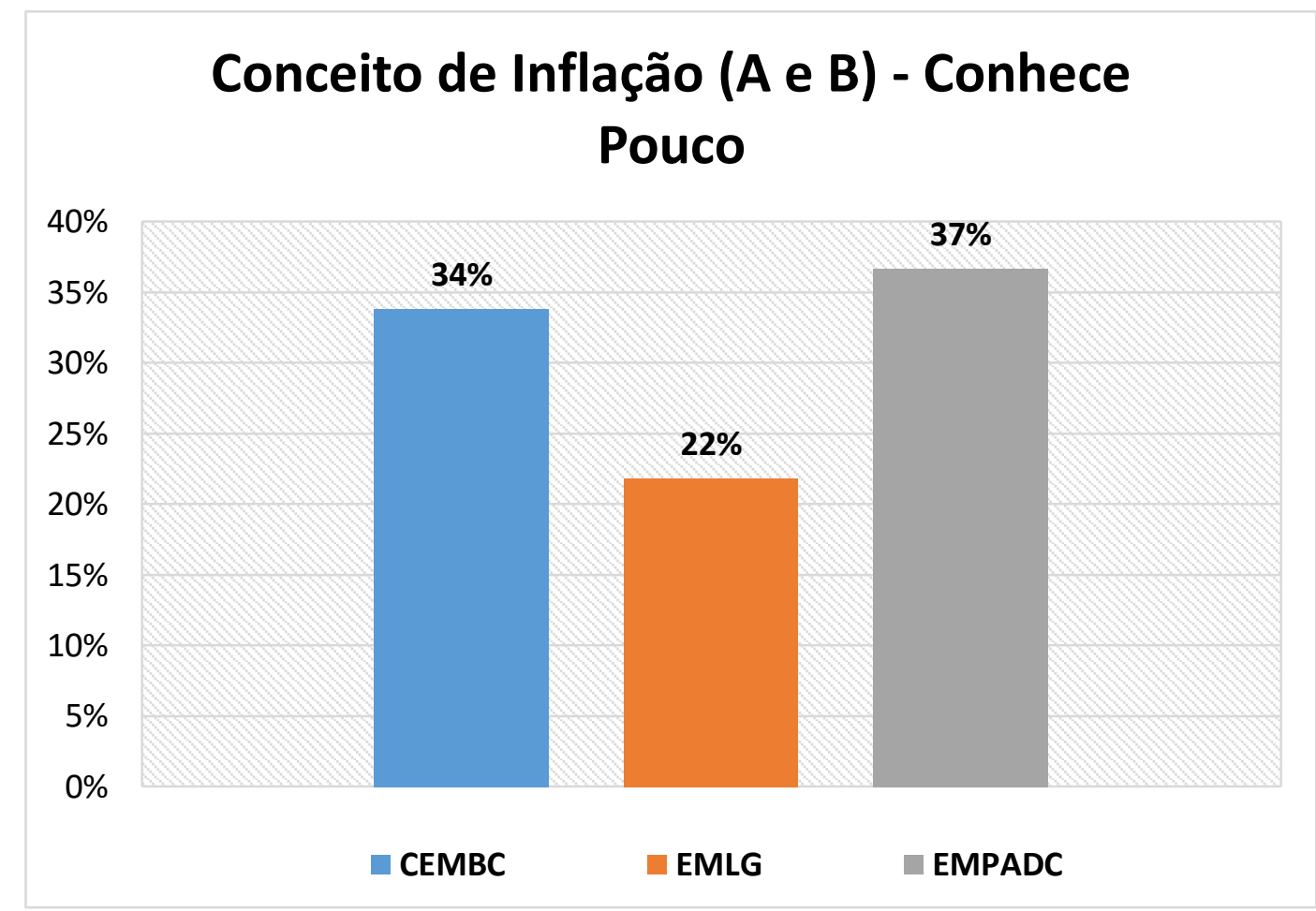

Figura 9: Gráfico de barras dos alunos que conhecem pouco sobre inflação nas 3 escolas. Fonte: a autora.

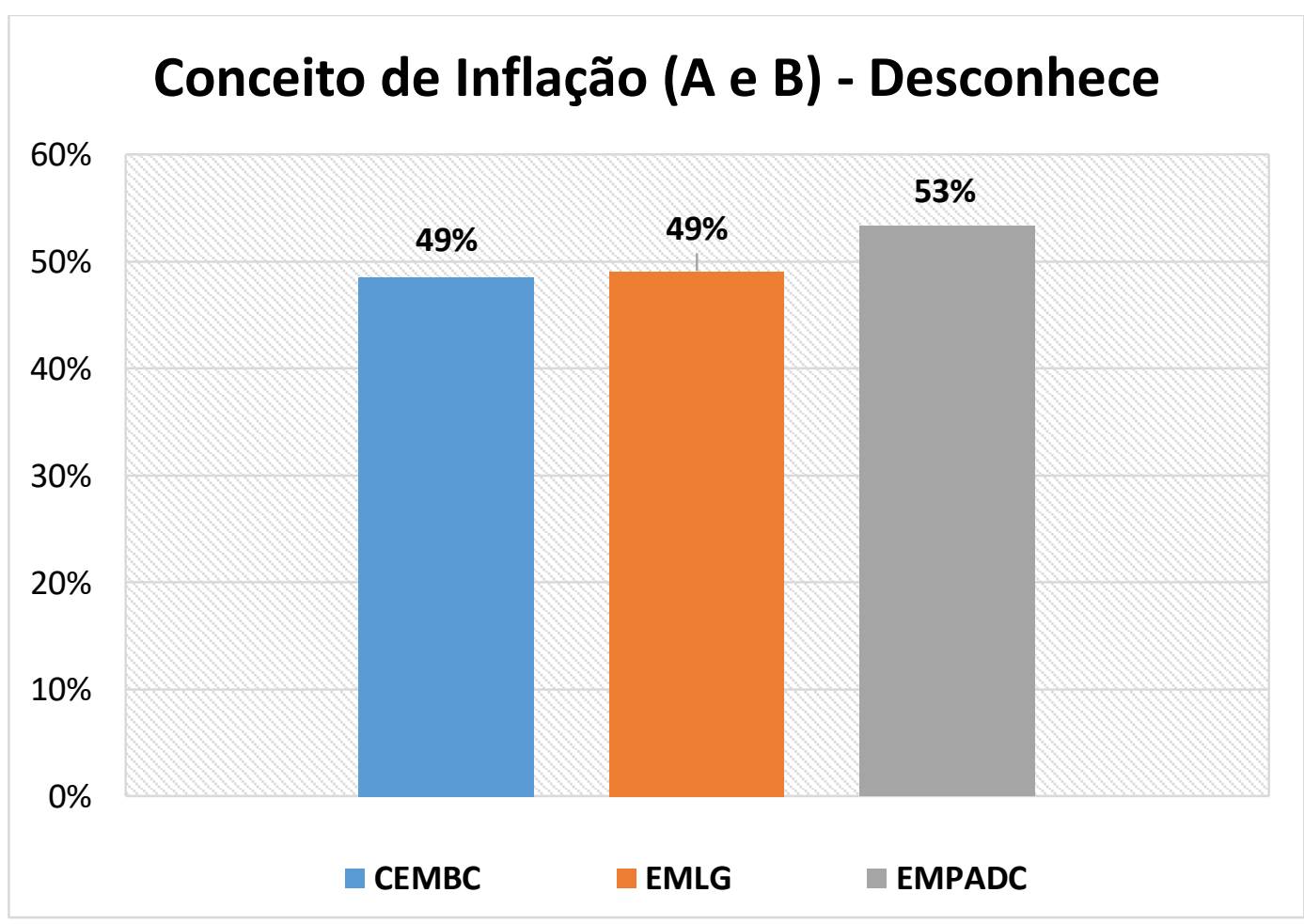

Figura 10: Gráfico de barras dos alunos que desconhecem sobre inflação nas 3 escolas. Fonte: a autora.

As perguntas (C) "Você conhece o termo deflação? Em caso positivo, o que ele significa." e (D) "A deflação interfere de forma positiva ou negativa na 
economia?" tem por objetivo complementar o conhecimento das perguntas anteriores. A figura 11 traz o percentual de alunos que conhecem o conceito de deflação, a figura 12 temos o percentual dos alunos que conhecem pouco e na figura 13 representam os alunos que desconhecem do assunto.

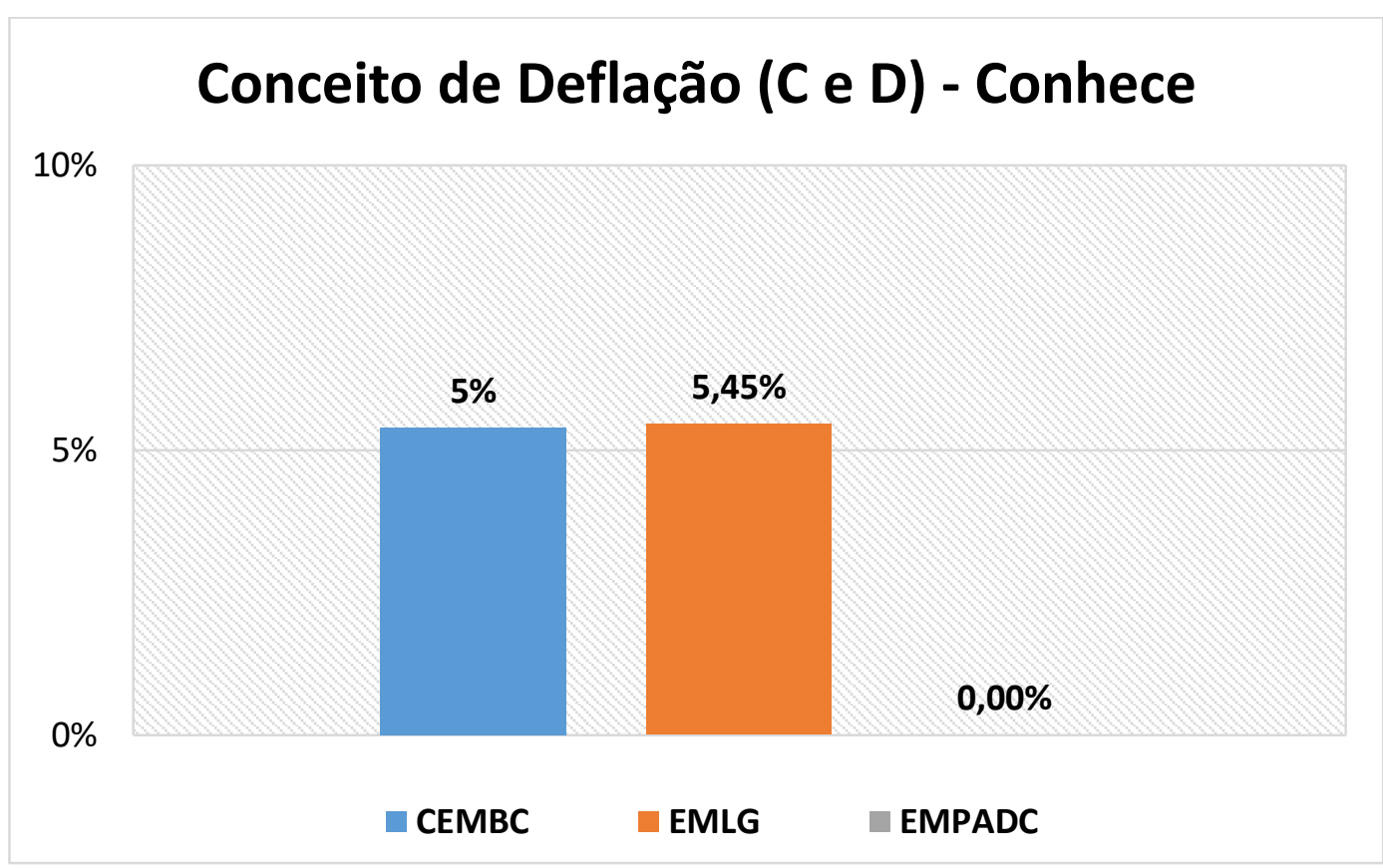

Figura 11: Gráfico de barras dos alunos que conhecem sobre deflação nas 3 escolas. Fonte: a autora. 


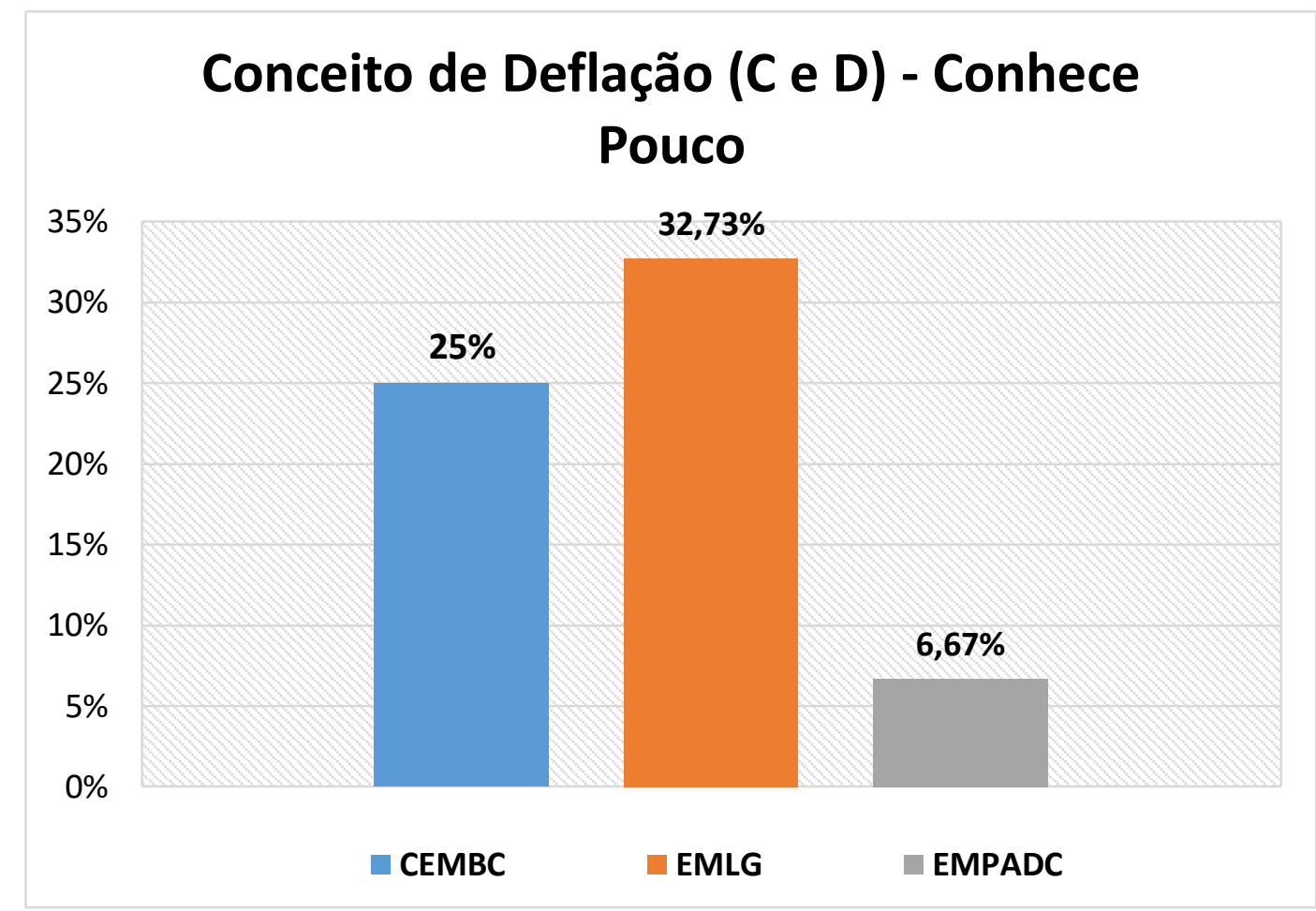

Figura 12: Gráfico de barras dos alunos que conhecem pouco sobre deflação nas 3 escolas.. Fonte: a autora.

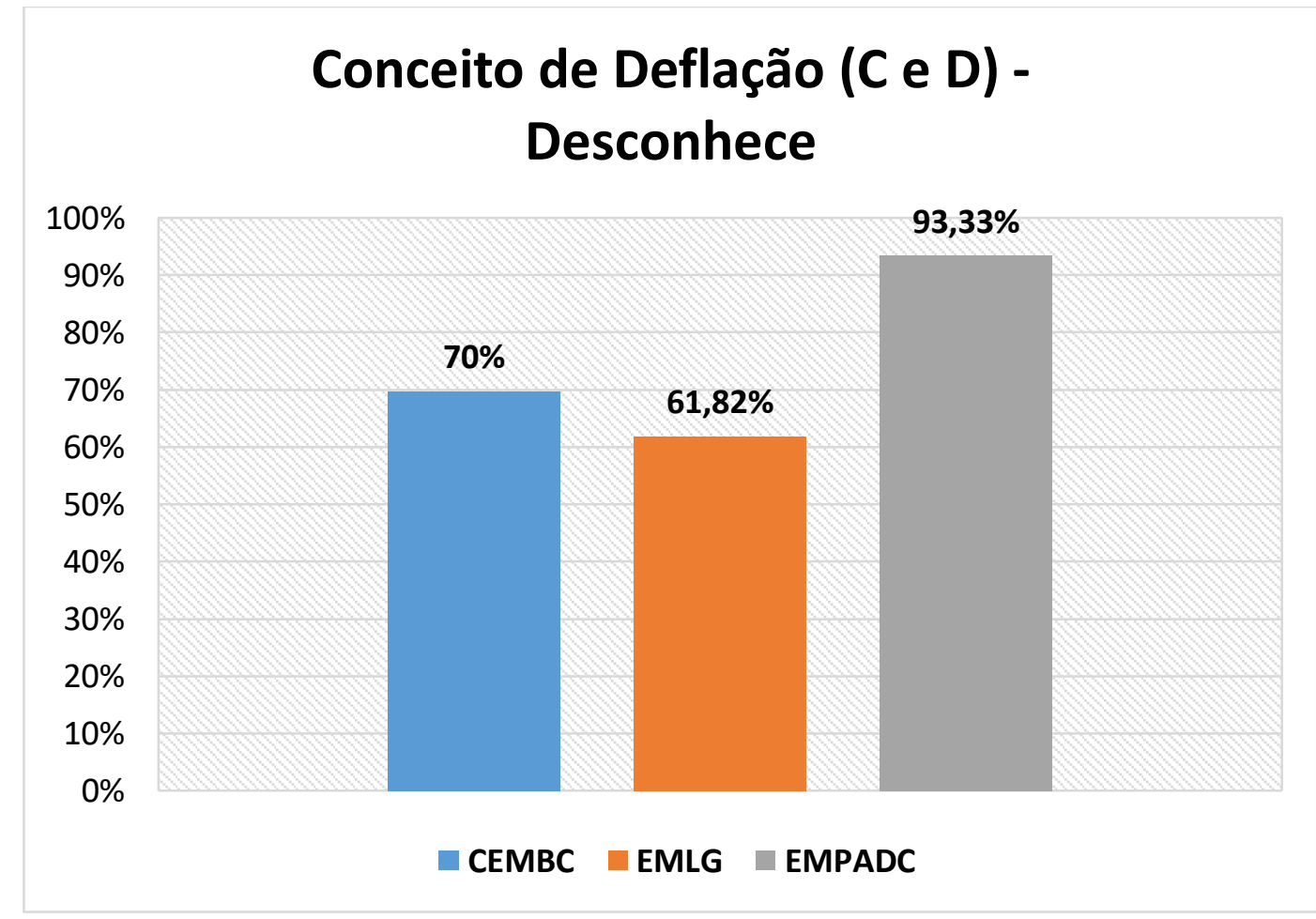

Figura 13: Gráfico de barras dos alunos que desconhecem sobre deflação nas 3 escolas. Fonte: a autora.

Podemos perceber que o percentual de alunos que desconhecem o que é inflação varia muito pouco, apenas 5 pontos percentuais entre a escola que teve o menor percentual para a que teve maior percentual. No entanto, o percentual de 
alunos que conhecem o que é inflação, variou de $10 \%$ para $29 \%$ entre as escolas avaliadas. Em consonância com esses dados temos, segundo Klapper et al. (2015) em seu trabalho embasado na pesquisa da Standard \& Poor's Rating (S\&P Global FinLit Survey) sobre Educação Financeira Global, que jovens, idosos, mulheres e pessoas de baixa renda formam um grupo vulnerável no que tange o tema. Isso fica evidenciado nesta análise, uma vez que a Escola Municipal Professora Aurelina Dias Cavalcanti pertence a uma região mais carente do município de São Gonçalo quando comparada Escola Municipal Luiz Gonzaga, que está situada numa região próxima a um dos principais centros comercial da cidade.

Em relação ao conhecimento sobre deflação podemos observar que o percentual dos que conhecem é baixíssimo, tornando muito expressivo a porcentagem dos que desconhecem. Atribuímos a isso uma certa imaturidade na vivência sobre o tema. A palavra inflação é comumente usada nos noticiários, enquanto que o fenômeno da deflação, por ser observado menos vezes, não é usualmente citado.

Nas perguntas (E) "O Brasil possui o Real como moeda econômica desde 1994 , você acha que $\mathrm{R} \$ 10,00$ hoje compram as mesmas coisas que compravam quando o Plano real começou?" e (F) "Levando em consideração que em 1995 o salário mínimo era $\mathrm{R} \$ 100,00$ e em 2020 é $\mathrm{R} \$ 1045,00$, responda, em qual época pode se comprar mais coisas? Justifique.”, tínhamos como objetivo avaliar o entendimento dos alunos sobre o poder de compra. Os resultados estão expostos a seguir nas figuras 14, 15 e 16. 


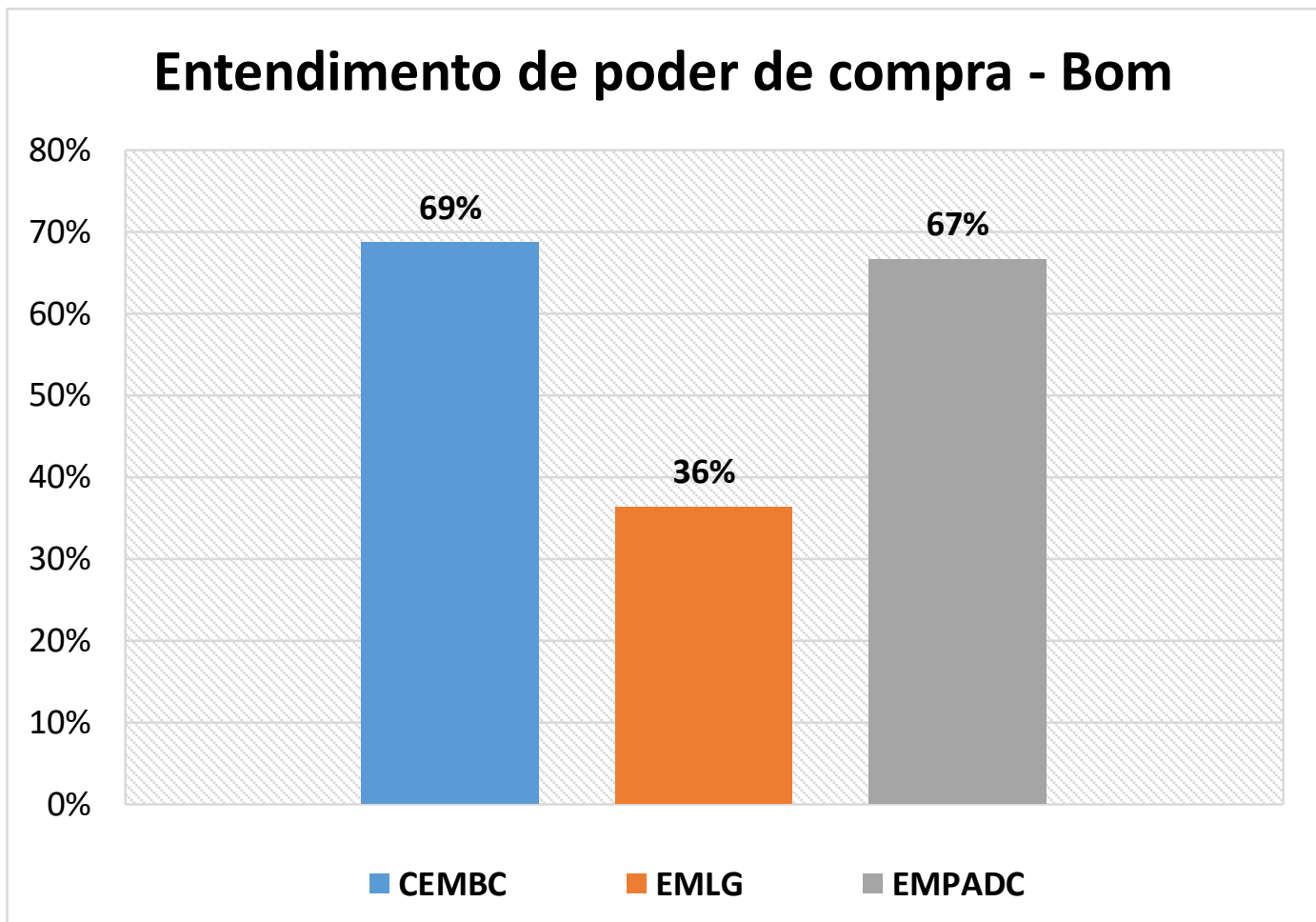

Figura 14: Gráfico de barras dos alunos que possuem bom entendimento sobre poder de compra nas 3 escolas. Fonte: a autora.

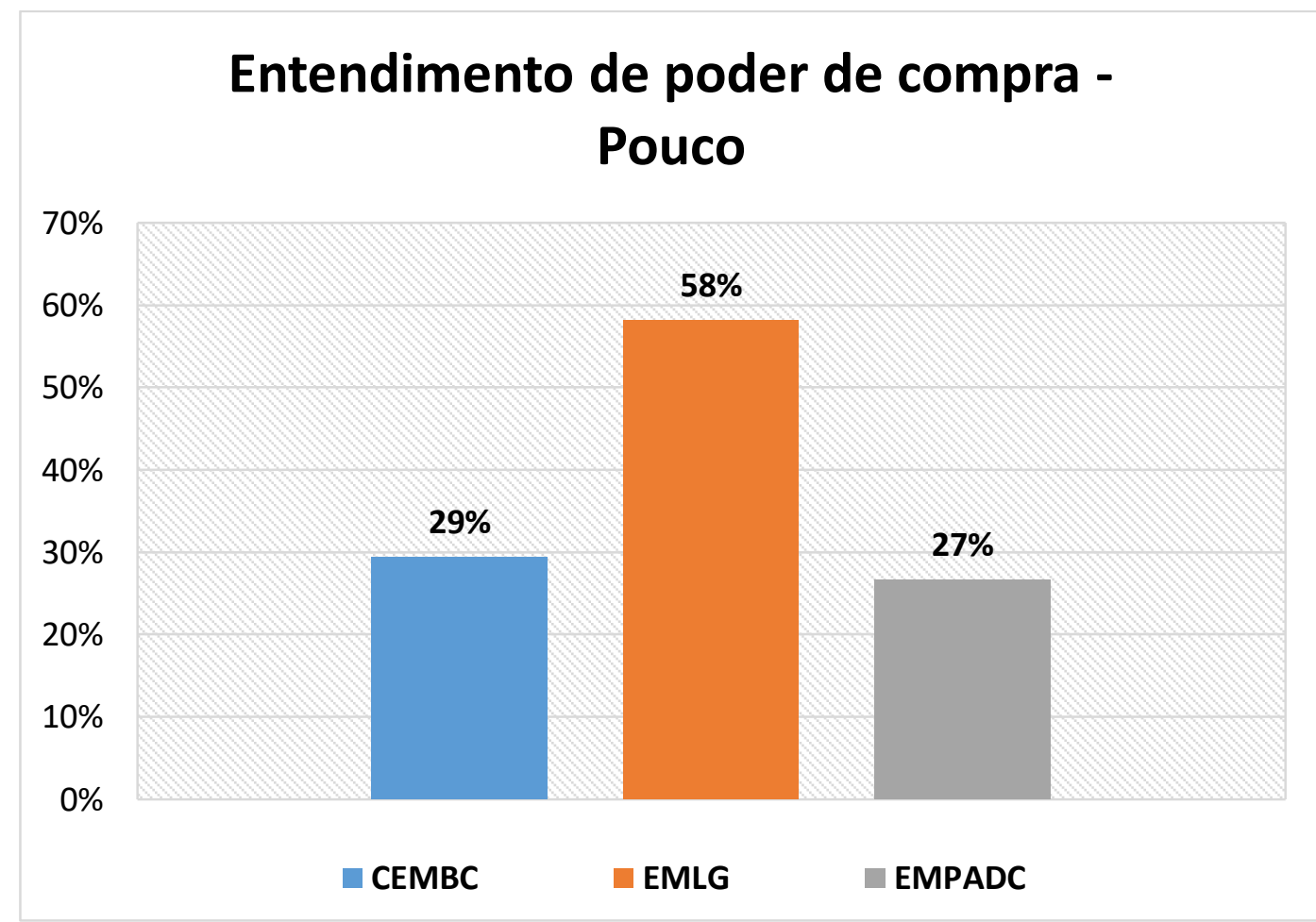

Figura 15: Gráfico de barras dos alunos que possuem pouco entendimento sobre poder de compra nas 3 escolas.. Fonte: a autora. 


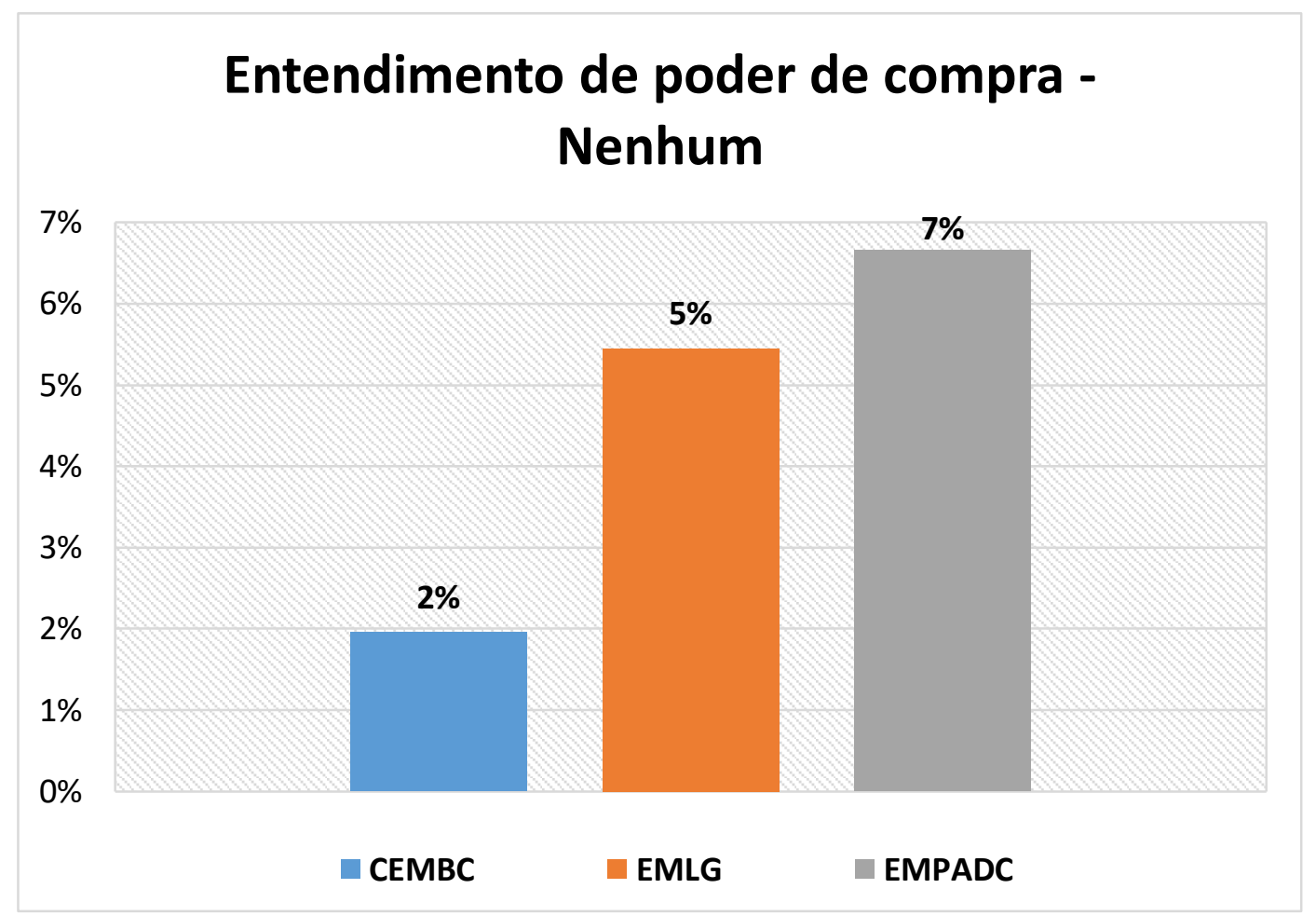

Figura 16: Gráfico de barras dos alunos que possuem nenhum entendimento sobre poder de compra nas 3 escolas. Fonte: a autora.

O que podemos observar é que mesmo sem saber explicar o que é inflação, a maioria dos alunos da EMPADC e do CEMBC tinham entendimento do poder de compra. Eles conseguiam perceber que existe variação nos preços e isso afeta a quantidade que uma determinada quantia pode comprar com o passar do tempo. Já na EMLG, onde tínhamos o maior percentual de alunos que conheciam o conceito de inflação, é a escola onde verificamos o percentual de bom entendimento de poder de compra. Isso nos leva a concluir que esses alunos possuem pouco contato com decisões que envolvem consumo.

Depois de recolher o questionário de todos os alunos, trabalhamos os conceitos de inflação, deflação e poder de compra com eles, explicando cada tópico e exemplificando de que forma esses conteúdos se apresentavam no cotidiano deles e de suas famílias.

\subsection{Atividade 2 - Planejamento e Orçamento Doméstico.}

$\mathrm{Na}$ aula seguinte à aplicação desse questionário, eu levei para os alunos uma atividade, modificada a partir do trabalho de Losano (2013), que contemplava o planejamento do orçamento doméstico. Para a resolução dessas atividades 
organizamos as classes em grupos de três alunos, para que eles pudessem discutir entre si suas vivências e conclusões. A primeira questão tratava sobre o valor que um casal de irmão deveria ganhar para cobrir todas as despesas mensais deles. $\mathrm{Na}$ figura 17 temos a questão em sua íntegra.

A atividade tem uma proposta simples, os alunos deveriam fazer o cálculo do gasto semanal de cada um dos personagens expostos na questão e em seguida chegar no valor mensal, para então verificar se o valor proposto de mesada pelo pai das crianças daria para cobrir todos os gastos que eles possuem. Alguns alunos perguntaram se poderiam usar calculadora, muito embora os cálculos não fossem complexos, autorizamos o uso da ferramenta, pois percebemos que seria um momento oportuno para aprimorar o uso desse recurso. 
Atividade 2

2.1)

No intuito de despertar seus filhos, Júlio e Hannah, para importância do planejamento financeiro pessoal, Bruno propôs a cada um deles o valor mensal em dinheiro (mesada) de R\$300,00. Cientes de que nenhum outro dinheiro será dado ao longo do mês eles devem organizar e planejar seus próprios gastos.

Orientados por seu pai eles esboçaram os cálculos de quanto gastavam por semana com cada item, conforme o indicado abaixo:

\begin{tabular}{|l|l|}
\hline \multicolumn{2}{|l|}{ Júlio } \\
\hline $\begin{array}{l}\text { Lanche na escola }\left(2^{\mathrm{a}} \text { a } 6^{\mathrm{a}}\right. \\
\text { feira) }\end{array}$ & $\begin{array}{l}3,00 \text { por dia } \\
=15,00\end{array}$ \\
\hline $\begin{array}{l}\text { Transporte para escola }- \\
\text { ida e volta - }\left(2^{\mathrm{a}} \text { a } 6^{\mathrm{a}} \text { feira) }\right.\end{array}$ & $\begin{array}{l}7,90 \times 5= \\
39,50\end{array}$ \\
\hline Açaí (3 vezes por semana) & $\begin{array}{l}5,00 \times 3= \\
15,00\end{array}$ \\
\hline $\begin{array}{l}\text { Saida aos sábados com os } \\
\text { amigos }\end{array}$ & 15,00 \\
\hline Jogos online & 10,00 \\
\hline
\end{tabular}

\begin{tabular}{|l|l|}
\hline \multicolumn{2}{|l|}{ Hannah } \\
\hline $\begin{array}{l}\text { Lanche na escola }\left(2^{\mathrm{a}} \text { a } 6^{\mathrm{a}}\right. \\
\text { feira })\end{array}$ & $\begin{array}{l}2,00 \text { por dia } \\
=10,00\end{array}$ \\
\hline $\begin{array}{l}\text { Transporte para escola }- \\
\text { ida e volta - }\left(2^{\mathrm{a}} \text { a } 6^{\mathrm{a}} \text { feira }\right)\end{array}$ & $\begin{array}{l}7,90 \times 5= \\
39,50\end{array}$ \\
\hline $\begin{array}{l}\text { Saída aos sábados com as } \\
\text { amigas }\end{array}$ & 20,00 \\
\hline $\begin{array}{l}\text { Algumas compras na } \\
\text { semana }\end{array}$ & 10,00 \\
\hline Cinema no domingo & 13,00 \\
\hline
\end{tabular}

Ao olhar as despesas de seus filhos, Bruno ficou pensando nas seguintes questões que sugerimos que você também pense e responda para entender o que está se passando, financeiramente, com Júlio e Hannah.

A) O dinheiro que Júlio e Hannah receberão de mesada será suficiente para seus gastos durante o mês (4 semanas), considerando que todas as semanas eles gastam a mesma quantia?

B) Que corte nos gastos semanais você sugere que deveria ser feito para que eles gastem somente o que ganham de mesada? Faça as contas.

C) Quantos reais cada um dos irmãos economizaria se na volta da escola fossem a pé?

Figura 17: Ficha da atividade 2.1 - Orçamento Familiar. Fonte: a autora.

O aproveitamento foi muito bom, a maioria dos grupos conseguiu chegar a uma conclusão correta no item (a), onde perguntava se o valor proposto pelo pai das crianças seria o suficiente para eles. A reposta correta era: não, cada um dos irmãos gastaria por mês mais que o valor da mesada. No item (b), onde perguntava quais os gastos poderiam ser evitados para que o valor da mesada fosse suficiente para cada um dos irmãos, tivemos as mais diversas respostas. As respostas a esse item ajudam a compreender as práticas e vivências do público atendidos em cada 
escola. Por exemplo, no CEMBC, foi muito recorrente a sugestão de cortar o transporte para a escola, e isso se justifica pelo fato da maioria dos alunos dessa escola morarem no entorno da mesma, sendo assim vão a pé para escola. Na EMLG essa sugestão não apareceu com frequência, pois muito dos alunos que ali estudam moram mais afastados da escola ou até em outros bairros, e por isso a condução é essencial. Nesta unidade de ensino e na EMPADC, foi mais comum a sugestão de eliminar as saídas com amigos.

A questão seguinte, ainda em conexão com o contexto da anterior, apresentava a eles uma planilha de receitas e despesas de um grupo familiar, um orçamento doméstico conforme a figura 18.

\section{2)}

Para integrar os filhos nas decisões financeiras domésticas, Bruno mostrou a eles o seu orçamento familiar, que compreende duas tabelas: Receitas (valor recebido) e Despesas (valor a pagar).

\begin{tabular}{|c|c|c|c|}
\hline \multicolumn{4}{|l|}{ MÊS: JANEIRO } \\
\hline \multicolumn{2}{|l|}{ RECEITAS } & \multicolumn{2}{|l|}{ DESPESAS } \\
\hline Salário do Pai & 1200,00 & Aluguel & 500,00 \\
\hline Salário da Mãe & 1100,00 & Água & 80,00 \\
\hline \multirow[t]{7}{*}{ TOTAL } & & Luz & 150,00 \\
\hline & & Supermercado & 700,00 \\
\hline & & Telefone (fixo) & 20,00 \\
\hline & & Celular & 40,00 \\
\hline & & Transporte & 630,00 \\
\hline & & Farmácia & 70,00 \\
\hline & & TOTAL & \\
\hline
\end{tabular}

A) Faça as contas do total da receita e das despesas e veja o que está acontecendo no orçamento de janeiro.

B) Muitas vezes surgem situações imprevistas que geram despesas extras no orçamento, por exemplo, suponha que em fevereiro, Júlio tenha que ir ao dentista cuja consulta custa $\mathrm{R} \$ 50,00$ e que a máquina de lavar precise de conserto orçado em R\$100,00. Com base no orçamento de janeiro, tendo em vista essas despesas extras, será possível pagar todas as despesas?

C) Quais sugestões você daria para que o saldo final não seja devedor?

Figura 18: Ficha da atividade 2.2 - Orçamento Familiar. Fonte: a autora. 
Antes de pedir para que os alunos fizessem a questão 2.2, foi explicado a eles que receita são os valores que ganhamos e representam crédito para as pessoas, no contexto da questão, as receitas eram os valores dos salários dos pais. E despesas são os gastos, nessa situação representados por: aluguel, conta de água, conta de luz, supermercado, contas de telefone, transporte e farmácia. Em seguida eles fizeram o total das receitas e das despesas, avaliando o que sobravam 110 reais nesse orçamento familiar.

No item (b), o exercício trazia duas despesas extras que somadas dariam 150 reais, e com isso não seria possível pagar todas as despesas, por isso no item (c) pedimos sugestões para que o saldo final não fosse devedor. Tivemos mais uma vez um conjunto muito variado de sugestões, algumas delas foram: cortar o telefone fixo, já que tinham celular; economizar no mercado; economizar no consumo de luz; trabalhar mais (fazer horas-extras ou um “bico”);

Para fecha as atividades de orçamento e planejamento doméstico, foi pedido que eles pensassem em seus gastos semanais e montassem uma tabela com eles para que pudessem propor um valor de mesada. Mas a maioria alegou não possuir gastos durante a semana com nada, pois não gastam com passagem em função do riocard escolar e o lanche na escola é gratuito. Diante desses argumentos, foi sugerido então que eles em casa abordassem o tema com seus responsáveis para que pudesse ser feito um orçamento doméstico com suas famílias.

Cabe ressaltar que todos possuem algum tipo de consumo, mesmo que eles não consigam identificar e colocar numa tabela. Então, ficou também como sugestão para eles que passassem a anotar em um caderno ou bloco, seus gastos, ainda que pequenos. Quando comprarem uma bala, anotem. Quando comprarem um refrigerante, anotem. Quando comprarem um lanche, anotem. E assim por diante para que possam enxergar seus gastos e suas formas de consumo.

\subsection{Atividade 3 - Porcentagem e Juros.}

No nosso terceiro encontro levamos propostas de atividades que trabalhassem os conceitos de desconto e aumento, juros simples e compostos. Para trabalhar esses tópicos foram usadas atividades adaptadas do trabalho Sugestões de Atividades de Educação Financeira para o Ensino de Muniz, Rodrigues e Victer (2018). Antes de 
propor os exercícios houve uma explanação sobre os temas, tratamos dos aumentos e descontos utilizando os fatores multiplicativos $(1+i)$ e $(1-i)$. Foram também exemplificados os juros simples e compostos para que em seguida fossem propostos os exercícios.

\section{Atividade 3}

3.1) No primeiro dia do mês de dezembro, um produto estava sendo comercializado por RS 100,00 . No décimo dia do mesmo mês, esse produto teve uma redução de $20 \%$ do seu valor. No vigésimo dia, ele foi reajustado com um aumento de $20 \%$. O produto estava mais barato no primeiro dia do que no vigésimo dia? Justifique sua resposta.

Figura 19: Exercício 3.1 da atividade 3 - Desconto e aumento. Fonte: a autora.

No primeiro exercício (Figura 19) percebemos que a resposta inicial dos alunos era que o produto não havia sofrido mudança após reduzir e aumentar a mesma taxa percentual. Mas quando solicitados a fazerem as contas para justificar suas respostas se surpreendiam com o resultado inferior ao inicial. Isso se dava ao fato de que a redução de $20 \%$ era sobre 100 reais, gerando o preço de 80 reais para esse produto e o aumento de $20 \%$ se dava sobre esse novo valor, chegando ao preço final de 96 reais. 
3.2) Constatamos que o empréstimo de dinheiro se trata de uma situação de uso corrente. Nesse sentido, sabemos que quando emprestamos algo a alguém demonstramos confiança. É comum aos cidadãos pedir empréstimos bancários e, também, a outras pessoas. Assim, ao emprestarmos dinheiro, além de receber o valor emprestado, no tempo combinado para devolvê-lo, esperamos receber um acréscimo em cima desta quantia, ou seja, um juro cobrado pelo tempo em que o dinheiro ficou em posse de outro. Os juros existem por vários fatores, podemos citar, por exemplo, a inflação que faz com que o dinheiro sofra desvalorização com o tempo. Com isso, o dinheiro emprestado tende a diminuir o seu valor durante o periodo do empréstimo. Caso alguém empreste R\$ 500,00 para outra pessoa num determinado dia e ao recebê-lo de volta após um ano, o que esta pessoa compraria com a mesma quantia não será a mesma coisa que poderá comprar depois de um ano; geralmente é menos. Por esse motivo, pelos riscos de quem empresta, existem os juros para compensar os possíveis prejuízos que a pessoa ou a instituição financeira pode vir a ter com a operação de empréstimo.

(A) A partir do texto acima, enumere os possíveis riscos que um cidadão ou um banco podem ter ao adquirir um empréstimo financeiro.

(B) Por qual motivo as pessoas pagam juros quando compram um produto a prazo? Qual seu posicionamento a respeito desta transação? Há uma operação de empréstimo?

Figura 20: Exercício 3.2 da atividade 3 - juros. Fonte: a autora.

O exercício 3.2 (Figura 20) não exigia habilidades matemáticas, mas trazia um questionamento interessante no ponto de vista da Educação Financeira, já que leva os alunos a refletirem sobre os riscos de se adquirir um empréstimo e o que é o juro. Também gera a reflexão de que uma compra a prazo com juros é um tipo de empréstimo, muitos não enxergam dessa forma. Com essa questão podemos ainda trazer à tona a temática do consumo consciente e planejado, enfatizando que é sempre melhor buscar poupar antes de consumir para que não tenha que desembolsar valores a mais com juros.

Na figura 21, temos o exercício 3.3, onde abordamos os juros simples, numa situação hipotética. No entanto, foi esclarecido aos alunos que em nossas transações financeiras reais dificilmente nos deparamos com essa modalidade de juro, em regra, o que se usa para financiamentos, são juros compostos. No exercício 3.4 (figura 21) o objetivo é avaliar duas situações distintas para pagamento e observar a diferença percentual entre elas. 
3.3) Uma concessionária de automóveis anunciou a venda de um carro zero, oferecendo duas formas de pagamento: RS $40.000,00$ à vista ou entrada de $50 \%$ e o saldo em 48 parcelas mensais, com taxa de $3 \%$ ao mês sobre o valor financiado no sistema de juros simples. Para calcular e responder:

(A) Qual é o valor de entrada, se esse carro for pago parceladamente?

(B) Qual o valor total a ser pago nas 48 parcelas?

(C) Após pagar todas as parcelas e a entrada, qual o valor total pago pelo carro?
3.4) Pedro quer comprar um Notebook em uma loja de informática perto de seu trabalho. A loja disponibiliza duas formas de pagamento: caso efetue a compra à vista, o preço será de RS 2000,00 , porém, se realizar a compra a prazo, poderá dividir em 8 parcelas de RS 300,00 . Para calcular e discutir:

(A) Entre as duas possibilidades de efetuar o pagamento: a prazo ou à vista, é possível perceber alguma diferença? Faça os seus cálculos e registre.

(B) Há vantagem em se comprar à vista o Notebook? Explique.

(C) No pagamento parcelado, qual é a taxa de juros em 8 meses?

Figura 21: Exercícios 3.3 e 3.4 da atividade 3 - juros simples. Fonte: a autora.

Por último foi trabalhado um exercício sobre juros compostos (figura 22), que poderia ser resolvido sem o uso de fórmulas, somente aplicando aumentos sucessivos, já que o prazo era curto (3 meses). A intenção era que os alunos entendessem o conceito de juros compostos, sem que isso se tornasse numa reprodução automática de fórmulas. No entanto, foi salientado que para prazos mais longos as fórmulas e calculadoras são instrumentos mais que bem-vindos.

3.5) Paulinho, aos 24 anos, resolveu empreender com uma uma franquia especializada na comercialização de publicidade em sacos de pão. Para tanto, ele precisou fazer um empréstimo bancário de RS $10.000,00$ para pagar em 90 dias com acréscimo de $5 \%$ ao mês, no regime de juros compostos.

A) Pelo empréstimo que Paulinho optou por fazer, quanto deverá devolver ao banco ao final de 90 dias?

B) Caso, ele devolva com 30 dias de antecedência, quanto ele devolverá?

Figura 222: Exercício 3.5 - juros compostos. Fonte: a autora.

Inicialmente foram elaboradas cinco atividades para o presente trabalho, no entanto as duas últimas, que tratavam sobre poupança, valor presente e valor futuro, não puderam ser aplicadas devido a suspensão das aulas presenciais em decorrência da pandemia de Covid-19. A resposta dos alunos às atividades remotas era muito 
baixa e assíncrona, de modo que impossibilitou a aplicação das duas últimas atividades e uma avaliação posterior dos impactos gerados pelos temas abordados.

Embora as atividades tenham sido aplicadas em turmas de $8^{\circ}$ ano e $9^{\circ}$ ano, podemos sugeri-las para turmas do $6^{\circ}$ ano ou $7^{\circ}$ ano, pois os elementos matemáticos necessários para as resoluções são habilidades previstas desde o $6^{\circ}$ ano pela BNCC. 


\section{5. \\ Considerações Finais.}

O intuito principal do presente trabalho é despertar no aluno o interesse pelo conhecimento acerca da educação financeira através de uma de suas ferramentas, a matemática. Com a obrigatoriedade do tópico como tema transversal da BNCC a educação financeira ganha força para estar cada vez mais presente nas salas de aulas, trazendo para o ambiente escolar discussões do nosso cotidiano conectando o aprendizado teórico com a utilização prática das ferramentas matemática. É preciso apresentar desde cedo para as crianças esses elementos que darão a elas recursos para lidar com seu próprio dinheiro e assim consumirem de forma consciente.

No decorre das atividades que exigiam habilidades numéricas ficou evidente como alguns alunos, embora saibam calcular porcentagem, por vezes não sabem contextualizar e aplicar essa teoria. Por fazer parte do dia a dia deles, a contextualização da matemática financeira se torna atraente e prende a atenção dos alunos. Torna-se primordial então que os conteúdos como porcentagem, juros simples, juros compostos, sejam apresentados de forma que estabeleçam um link com a realidade vivenciada pelos alunos, agregando valores a conceitos corriqueiros como inflação, poder de compra, planejamento financeiro e tantos outros.

Esperamos que esse trabalho possa colaborar para aumentar o repertório motivacional dos professores presentes no Ensino Básico, em especial aos atuantes no segundo segmento do Ensino Fundamental, para que estes possam ser multiplicadores na formação de seus alunos como cidadãos, fornecendo um conjunto de técnicas e habilidades que os proporcionem liberdade de escolhas e equilíbrio financeiro. 


\section{Referências}

ARAÚJO, M. Pílulas de Matemática Financeira (2). 2013. Disponível em: $<$ http://profmilton.blogspot.com.br/2013/12/pilulas-de-matematica-financeira2.html> acesso em: 17 jun. 2020.

BACEN. Circular n ${ }^{\circ}$ 1.273, de 29 de dezembro de 1987. Banco Central do Brasil, $1987 . \quad$ Disponível em: 〈https://www.bcb.gov.br/pre/normativos/circ/1987/pdf/circ_1273_v1_o.pdf> acesso em: 17 jun. 2020.

BACEN. Resolução n 3.517, de 06 de dezembro de 2007. Banco Central do Brasil, 2007. Disponível

em:

<https://www.bcb.gov.br/pre/normativos/busca/downloadNormativo.asp?arquivo =/Lists/Normativos/Attachments/48005/Res 3517 v1 O.pdf $>$ acesso em: 17 jun. 2020 .

BRASIL, Base Nacional Comum Curricular - BNCC. Disponível em: $<$ http://basenacionalcomum.mec.gov.br/images/BNCC_EI_EF_110518_versaofin al_site.pdf > acesso em: 17 jun. 2020.

BRASIL, Constituição da República Federativa do Brasil, de 05 de outubro de 1988. Brasília, DF, 05 out. 1988. Disponível em: <http://www.planalto.gov.br/ccivil 03/constituicao/constituicaocompilado.htm > acesso em: 17 jun. 2020.

BRASIL, Decreto $n^{\circ} 10393$, de 09 de junho de 2020. Institui a nova Estratégia Nacional de Educação Financeira - ENEF e o Fórum Brasileiro de Educação Financeira - FBEF. Disponível <http://www.planalto.gov.br/ccivil_03/_Ato20192022/2020/Decreto/D10393.htm> acesso em: 17 jun. 2020.

BRASIL, Decreto $\mathrm{n}^{\mathrm{o}}$ 7397, de 22 de dezembro de 2010. Institui a Estratégia Nacional de Educação Financeira - ENEF, dispõe sobre a sua gestão e dá outras providências. Disponível em: 
<http://www.planalto.gov.br/ccivil_03/_Ato2007-

2010/2010/Decreto/D7397.htm> acesso em: 17 jun. 2020.

BRASIL, Estratégia Nacional de Educação Financeira: Plano Diretor da ENEF. Disponível

em: <https://www.vidaedinheiro.gov.br/docs/PlanoDiretorENEF1.pdf $>$ acesso em: 17 jun. 2020.

BRASIL, Infográfico ENEF, 2010. Disponível em: <https://www.vidaedinheiro.gov.br/wp-content/uploads/2019/07/Infograficofrente-mesclado.pdf $>$ acesso em: 17 jun. 2020.

CERBASI, G. Como organizar sua vida financeira: Inteligência financeira pessoal na prática. Rio de Janeiro: Elsevier, 2009. 159p.

FERREIRA, G. IPCA, IGP-M, INPC... Qual a inflação verdadeira?. Valor Investe, São Paulo, maio 2019. Seção Brasil e Política. Disponível em: $<$ https://valorinveste.globo.com/mercados/brasil-epolitica/noticia/2019/05/03/ipca-igp-m-inpc-qual-a-inflacao-verdadeira.ghtml> acesso em: 17 jun. 2020.

GUimarẽES, A. A. Matemática Financeira: Proposta de atividades para o Ensino Médio sob uma perspectiva da Educação Financeira. 2018. Dissertação PROFMAT, Universidade Federal do Rio de Janeiro - Rio de Janeiro, 2018. 64f. Disponível em: <https://sca.profmatsbm.org.br/sca v2/get tcc3.php?id=150500569> acesso em: 17 jun. 2020.

KLAPPER, L.; LUSARDI, A.; OUDHEUSDEN, P.V. (2015). Financial Literacy around the World. Washington DC: Standard \& Poor's Ratings Services Global Financial Literacy Survey. Disponível em: <https://responsiblefinanceforum.org/wp-content/uploads/2015/12/2015Finlit_paper_17_F3_SINGLES.pdf> acesso em: 17 jun. 2020.

LOSANO, L. A. B. Design de Tarefas de Educação Financeira para o $6^{\circ}$ ano do Ensino Fundamental. 2013. 120f. Dissertação - Instituto de Ciências Exatas, Universidade Federal de Juiz de Fora, Minas Gerais, 2013. Disponível em: $<$ https://www2.ufjf.br/mestradoedumat/wp- 
content/uploads/sites/134/2011/05/Luciana-Aparecida-Borges-Losano.pdf> acesso em: 17 jun. 2020.

MICHAELIS. Dicionário Online - Etimologia e significado de Crédito. Disponível em < https://michaelis.uol.com.br/moderno-portugues/busca/portuguesbrasileiro/credito> acesso em: 17 jun. 2020.

MUNIZ, C. M. O.; RODRIGUES, C. K.; VICTER E. F. Sugestões de Atividades de Educação Financeira para o Ensino. Material de apoio para práticas pedagógicas de professores de Matemática/ Carlos Magno Oliveira Muniz; Dra. Chang Kuo Rodrigues; Dra. Eline das Flores Victer. - $1^{\text {a }}$ Ed. - Duque de Caxias, RJ: UNIGRANRIO, 2018. Disponível em: 〈https://educapes.capes.gov.br/handle/capes/431413> acesso em: 17 jun. 2020.

MUNIZ, I. Jr. Finanças no Ensino Médio: Atividades da perspectiva da educação econômico-financeira. In: XI Encontro Nacional de Educação Matemática - XI ENEM, 2013 Curitiba, PR. Disponível em: $<$ http://sbem.iuri0094.hospedagemdesites.ws/anais/XIENEM/pdf/3486_1905_ID. pdf > acesso em: 17 jun. 2020.

OCDE. Organização de cooperação e de desenvolvimento econômico. Recommendation on principles and good practices for financial education and Awareness. 2005. Disponível em <https://www.oecd.org/finance/financialeducation/35108560.pdf> acesso em: 17 jun. 2020.

REIS, T. Índice Big Mac: entenda como funciona esse curioso índice econômico. $2019 . \quad$ Disponível em $<$ https://www.sunoresearch.com.br/artigos/indice-bigmac/\#: :text=O\%20\%C3\%8Dndice\%20Big\%20Mac\%20\%C3\%A9,Poder\%20de \%20Compra\%20(PPC)\%3E> acesso em: 17 jun. 2020.

SAITO, A. T. Uma contribuição ao desenvolvimento da educação em finanças no Brasil. 2008. 152f. Dissertação de Mestrado. FEA/USP - São Paulo

SILVA, S. L. M., BEZERRA, R. C. A educação financeira como uma proposta para uma vida economicamente equilibrada. Os desafios da escola pública 
paranaense na perspectiva do professor PDE - Produções Didático-Pedagógicas v.2 Paraná, 2016. 15p.

TOLOTTI, M. As armadilhas do consumo: acabe com o endividamento. Rio de janeiro: Rio de Janeiro: Elsevier, 2007. 144p 


\section{Apêndices}

\section{Atividade 1 - Questionário.}

A) O que você conhece sobre inflação?

B) A inflação é um termo muito presente em noticiário econômicos, dessa forma o que você julga ser melhor para a economia de um país, uma inflação alta ou baixa? Por que?

C) Você conhece o termo deflação? Em caso positivo, o que ele significa.

D) A deflação interfere de forma positiva ou negativa na economia?

E) O Brasil possui o Real como moeda econômica desde 1994, você acha que $\mathrm{R} \$ 10,00$ hoje compram as mesmas coisas que compravam quando o Plano real começou?

F) Levando em consideração que em 1995 o salário mínimo era R \$ 100,00 e em 2020 é $\mathrm{R} \$ 1045,00$, responda, em qual época pode se comprar mais coisas? Justifique. 


\section{Atividade 2 - Planejamento e Orçamento Doméstico.}

2.1) No intuito de despertar seus filhos, Júlio e Hannah, para importância do planejamento financeiro pessoal, Bruno propôs a cada um deles o valor mensal em dinheiro (mesada) de $R \$ 300,00$. Cientes de que nenhum outro dinheiro será dado ao longo do mês eles devem organizar e planejar seus próprios gastos.

Orientados por seu pai eles esboçaram os cálculos de quanto gastavam por semana com cada item, conforme o indicado abaixo:

\begin{tabular}{|l|l|}
\hline \multicolumn{2}{|l|}{ Júlio } \\
\hline Lanche na escola $\left(2^{\mathrm{a}}\right.$ a $6^{\mathrm{a}}$ feira $)$ & 3,00 por dia $=15,00$ \\
\hline Transporte para escola - ida e volta $-\left(2^{\mathrm{a}}\right.$ a $6^{\mathrm{a}}$ feira $)$ & $7,90 \times 5=39,50$ \\
\hline Açaí (3 vezes por semana) & $5,00 \times 3=15,00$ \\
\hline Saída aos sábados com os amigos & 15,00 \\
\hline Jogos online & 10,00 \\
\hline
\end{tabular}

\begin{tabular}{|l|l|}
\hline \multicolumn{2}{|l|}{ Hannah } \\
\hline Lanche na escola $\left(2^{\mathrm{a}}\right.$ a $6^{\mathrm{a}}$ feira $)$ & 2,00 por dia $=10,00$ \\
\hline Transporte para escola - ida e volta $-\left(2^{\mathrm{a}}\right.$ a $6^{\mathrm{a}}$ feira $)$ & $7,90 \times 5=39,50$ \\
\hline Saída aos sábados com as amigas & 20,00 \\
\hline Algumas compras na semana & 10,00 \\
\hline Cinema no domingo & 13,00 \\
\hline
\end{tabular}

Ao olhar as despesas de seus filhos, Bruno ficou pensando nas seguintes questões que sugerimos que você também pense e responda para entender o que está se passando, financeiramente, com Júlio e Hannah.

A) O dinheiro que Júlio e Hannah receberão de mesada será suficiente para seus gastos durante o mês (4 semanas), considerando que todas as semanas eles gastam a mesma quantia? 
B) Que corte nos gastos semanais você sugere que deveria ser feito para que eles gastem somente o que ganham de mesada? Faça as contas.

C) Quantos reais cada um dos irmãos economizaria se na volta da escola fossem a pé?

2.2) Para integrar os filhos nas decisões financeiras domésticas, Bruno mostrou a eles o seu orçamento familiar, que compreende duas tabelas: Receitas (valor recebido) e Despesas (valor a pagar).

\begin{tabular}{|l|l|l|l|}
\hline \multicolumn{2}{|l}{ MÊS: JANEIRO } & \multicolumn{2}{l|}{ DESPESAS } \\
\hline RECEITAS & 1200,00 & Aluguel & 500,00 \\
\hline Salário do Pai & 1100,00 & Água & 80,00 \\
\hline Salário da Mãe & & Luz & 150,00 \\
\hline TOTAL & & Supermercado & 700,00 \\
\hline & & Telefone (fixo) & 20,00 \\
\hline & & Celular & 40,00 \\
\hline & & Transporte & 630,00 \\
\hline & & Farmácia & 70,00 \\
\hline & TOTAL & \\
\hline
\end{tabular}

A) Faça as contas do total da receita e das despesas e veja o que está acontecendo no orçamento de janeiro.

B) Muitas vezes surgem situações imprevistas que geram despesas extras no orçamento, por exemplo, suponha que em fevereiro, Júlio tenha que ir ao dentista cuja consulta custa $\mathrm{R} \$ 50,00$ e que a máquina de lavar precise de conserto orçado em $\mathrm{R} \$ 100,00$. Com base no orçamento de janeiro, tendo em vista essas despesas extras, será possível pagar todas as despesas?

C) Quais sugestões você daria para que o saldo final não seja devedor?

2.3) Inspirado em Júlio e Hannah, monte uma tabela com coisas que você costuma gastar durante a semana e proponha um valor mensal para uma mesada. 


\section{Atividade 3 - Porcentagem e Juros.}

3.1) No primeiro dia do mês de dezembro, um produto estava sendo comercializado por $\mathrm{R} \$ 100,00$. No décimo dia do mesmo mês, esse produto teve uma redução de $20 \%$ do seu valor. No vigésimo dia, ele foi reajustado com um aumento de $20 \%$. O produto estava mais barato no primeiro dia do que no vigésimo dia? Justifique sua resposta.

3.2) Constatamos que o empréstimo de dinheiro se trata de uma situação de uso corrente. Nesse sentido, sabemos que quando emprestamos algo a alguém demonstramos confiança. É comum aos cidadãos pedir empréstimos bancários e, também, a outras pessoas. Assim, ao emprestarmos dinheiro, além de receber o valor emprestado, no tempo combinado para devolvê-lo, esperamos receber um acréscimo em cima desta quantia, ou seja, um juro cobrado pelo tempo em que o dinheiro ficou em posse de outro. Os juros existem por vários fatores, podemos citar, por exemplo, a inflação - que faz com que o dinheiro sofra desvalorização com o tempo. Com isso, o dinheiro emprestado tende a diminuir o seu valor durante o período do empréstimo. Caso alguém empreste $\mathrm{R} \$ 500,00$ para outra pessoa num determinado dia e ao recebê-lo de volta após um ano, o que esta pessoa compraria com a mesma quantia não será a mesma coisa que poderá comprar depois de um ano; geralmente é menos. Por esse motivo, pelos riscos de quem empresta, existem os juros para compensar os possíveis prejuízos que a pessoa ou a instituição financeira pode vir a ter com a operação de empréstimo.

A) A partir do texto acima, enumere os possíveis riscos que um cidadão ou um banco podem ter ao adquirir um empréstimo financeiro.

B) Por qual motivo as pessoas pagam juros quando compram um produto a prazo? Qual seu posicionamento a respeito desta transação? Há uma operação de empréstimo?

3.3) Uma concessionária de automóveis anunciou a venda de um carro zero, oferecendo duas formas de pagamento: $\mathrm{R} \$ 40.000,00$ à vista ou entrada de 50\% e o saldo em 48 parcelas mensais, com taxa de $3 \%$ ao mês sobre o valor financiado no sistema de juros simples. Para calcular e responder:

A) Qual é o valor de entrada, se esse carro for pago parceladamente? 
B) Qual o valor total a ser pago nas 48 parcelas?

C) Após pagar todas as parcelas e a entrada, qual o valor total pago pelo carro?

3.4) Pedro quer comprar um Notebook em uma loja de informática perto de seu trabalho. A loja disponibiliza duas formas de pagamento: caso efetue a compra à vista, o preço será de $\mathrm{R} \$ 1700,00$, porém, se realizar a compra a prazo, poderá dividir em 8 parcelas de $\mathrm{R} \$ 300,00$. Para calcular e discutir:

A) Entre as duas possibilidades de efetuar o pagamento: a prazo ou à vista, é possível perceber alguma diferença? Faça os seus cálculos e registre.

B) Há vantagem em se comprar à vista o Notebook? Explique.

3.5) Paulinho, aos 24 anos, resolveu empreender com uma franquia especializada na comercialização de publicidade em sacos de pão. Para tanto, ele precisou fazer um empréstimo bancário de $\mathrm{R} \$ 10.000,00$ para pagar em 90 dias com acréscimo de $5 \%$ ao mês, no regime de juros compostos.

A) Pelo empréstimo que Paulinho optou por fazer, quanto deverá devolver ao banco ao final de 90 dias?

B) Caso, ele devolva com 30 dias de antecedência, quanto ele devolverá? 